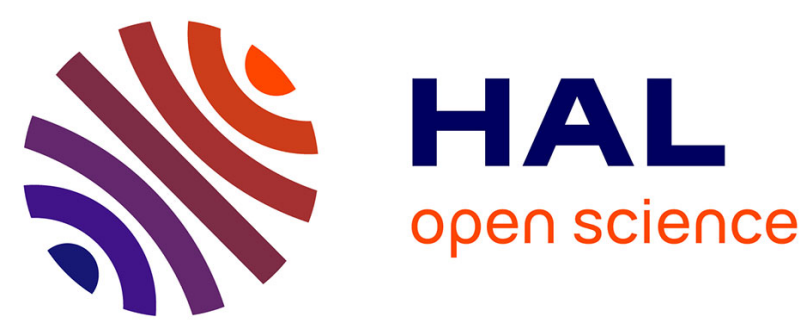

\title{
Drosophila suzukii oxidative stress response involves Jheh gene cluster but not transposable elements
}

Pierre Marin, Angelo Jacquet, Hélène Henri, Patricia Gibert, Cristina Vieira

\section{To cite this version:}

Pierre Marin, Angelo Jacquet, Hélène Henri, Patricia Gibert, Cristina Vieira. Drosophila suzukii oxidative stress response involves Jheh gene cluster but not transposable elements. 2020. hal-03014540

\section{HAL Id: hal-03014540 \\ https://cnrs.hal.science/hal-03014540}

Preprint submitted on 19 Nov 2020

HAL is a multi-disciplinary open access archive for the deposit and dissemination of scientific research documents, whether they are published or not. The documents may come from teaching and research institutions in France or abroad, or from public or private research centers.
L'archive ouverte pluridisciplinaire HAL, est destinée au dépôt et à la diffusion de documents scientifiques de niveau recherche, publiés ou non, émanant des établissements d'enseignement et de recherche français ou étrangers, des laboratoires publics ou privés. 
1 Title: Drosophila suzukii oxidative stress response involves Jheh gene cluster but not transposable 2 elements

4 Running title: $D$. suzukii stress response and Jheh

5

6 Authors : Pierre Marin ${ }^{1}$, Angelo Jacquet ${ }^{1}$, Hélène Henri ${ }^{1}$, Patricia Gibert ${ }^{1}$ \& Cristina Vieira ${ }^{1}$

7 'Laboratoire de Biométrie et Biologie Evolutive UMR 5558, CNRS, Université Lyon 1, Université

8 de Lyon, Villeurbanne, France

9 Corresponding author's email : patricia.gibert@univ-lyon1.fr, cristina.vieira@univ-lyon1.fr 10

11 Keywords: invasive species, gene expression, rapid adaptation, paraquat, genotypes 12 


\section{Summary statement}

31 The responses to oxidative stress of the invasive species, Drosophila suzukii, show variability between genotypes related to their invasion status. The genes of the juvenile hormone epoxide hydrolase cluster are involved in this response.

\section{ABSTRACT}

The study of the mechanisms involved in adaptation remains a timely issue, particularly in the context of global changes. To better understand these mechanisms of rapid adaptation, invasive species are a good model because they are subjected to new and/or different environmental factors. Using different lines of different geographical origin of the invasive pest Drosophila suzukii, we characterized the phenotypic response to oxidative stress. Subsequently, we tested the involvement of the Jheh gene cluster in this response and the possible role of transposable elements. We show that the resistance to oxidative stress of the lines appears to be related to their invasive status and we confirm the role of the Jheh gene cluster in this response. We have not identified any transposable elements in this gene region that could influence the expression of the gene.

\section{INTRODUCTION}

48 The rapid spread of invasive species in a huge spectrum of environments relies on multiple factors, from genetics to phenotypic plasticity, probably including fine molecular mechanism such as hormonal production or epigenetic gene regulation (Beldade et al., 2011; Marin et al., 2019; Stapley et al., 2015). Phenotypic plasticity, i.e., the ability of a genotype to express different phenotypes in different environments (Ghalambor et al., 2015) has been proposed as one of the most promising explanations for invasive success, particularly in the case of founder population depleted of genetic variation (Estoup et al., 2016; Marin et al., 2019). Among deleterious environments that can be encountered by invasive species, oxidative stress caused by phytosanitary products is one of them. The invasive pest, Drosophila suzukii, is a good model to investigate the adaptive process during invasion (Gibert et al., 2016). This species which belong to the group of the fruit fly $D$. melanogaster, originally comes from Asia and was detected simultaneously both in North America (U.S.A) and in Europe in 2008. North America was invaded by native Japan populations derived from Hawaii. In Europe, several introductions were detected from U.S.A and from China (Fraimout et al., 2017). Currently, D. suzukii is present in both North and South America, in Europe from the south (Spain) to the East (Poland, Ukraine) and it has 
64 Characterization of the phenotypic and molecular responses of $D$. suzukii to changing environmental conditions may provide information to the mechanisms involved in the ability of invasive species to cope with environmental variation. Paraquat (N,N'-dimethyl-4,4'-bipyridinium dichloride) is one of the most widely used herbicide in the world leading to the production of ROS (reactive oxygen species) (Tsai, 2018). Oxidative stress due to the use of paraquat in the field has also been used in the laboratory as a good proxy for studying stress resistance (Bus $\mathrm{J} S$ and Gibson J E, 1984; Rzezniczak et al., 2011). Paraquat was banned since 2007 in Europe but is still used in many other regions like in U.S.A or Japan. Paraquat exposition is known to induce a reduction in the lifespan associated with changes in gene expression (Finkel and Holbrook, 2000; Liguori et al., 2018; Vermeulen et al., 2005). One of the candidate genes involved in paraquat resistance is the cluster of Jheh (Juvenile hormone epoxide hydrolase) genes, which are not only involved in the lifespan but also in response to the oxidative environment (Flatt and Kawecki, 2007; Guio et al., 2014). Moreover in D. melanogaster, an insertion of a transposable element (TE) Bari-Jheh, near the cluster of the Jheh genes has been described as driving an increase of resistance in presence of paraquat (Guio et al., 2014).

Using several strains of $D$. suzukii, we measured responses to oxidative stress at the phenotypic and molecular level. We made the hypothesis that different genetic backgrounds from native and invasive populations will have different responses to oxidative stress and that the Jheh cluster may be involved on it. Due to the over-representation of TEs in the genome of D. suzukii (33\% of the repeated elements, (Sessegolo et al., 2016)), compared to other Drosophila species, we looked for the presence of TEs in this region in the different lines. We monitored lifespan after paraquat exposure and measured the expression of three genes of Jheh cluster Jheh-1, Jheh-2 and Jheh-3 in six isofemale lines, four from the invasive regions, North America (Watsonville and Dayton) and France (Paris and Montpellier) and two from the native area, Japan (Sapporo and Tokyo). We evaluated the genetic diversity within and between lines by sequencing introns of the Jheh genes, searched for TEs and for transcription factor binding sites (TFBS). Our results suggest a strong effect of the genotype on the resistance to stress and changes in Jheh expression levels, with no link with TEs.

\section{MATERIAL AND METHODS}

\section{Drosophila suzukii lines and rearing conditions}

D. suzukii lines were sampled in 2014 from one native country (Japan: Sapporo and Tokyo) and 2 invaded areas (USA: Watsonville and Dayton and France: Montpellier and Paris). Field- 
99 used to investigate Drosophila natural populations (David et al., 2005). Flies were reared in 00 modified medium (drosophila agar type, ref.66-103, Apex ${ }^{\mathrm{TM}}, 9 \mathrm{~g} . \mathrm{L}^{-1}$; cornmeal $33 \mathrm{~g} . \mathrm{L}^{-1}$; yeast, 01 dried yeast, ref.75570, LYNSIDE ${ }^{\circledR} 17$ g.L-1 ; industrial sugar 50 g.L L $^{-1}$; nipagin, Tegosept, ref.20-

02

03 258, Apex ${ }^{\mathrm{TM}} 4 \mathrm{~g} . \mathrm{L}^{-1} ; 96 \%$ ethanol $40 \mathrm{ml}^{-\mathrm{L}^{-1}}$; distilled water $1 \mathrm{~L}$ ) from Dalton et al., (2011), in a humidified, temperature-controlled incubator at $22.5^{\circ} \mathrm{C}, 70 \%$ of relative humidity and a 16:8 LD cycle. The recipe of the modified medium was to bring to boil agar, cornmeal, yeast extract and sugar in distilled water. Then wait out of the fire about 10 minutes until the mixture cooled to $53^{\circ} \mathrm{C}$ before adding diluted nipagin in $96 \%$ ethanol. Medium is then poured in vials and cooled at room temperature before to be stored at $4^{\circ} \mathrm{C}$. All the experiments were made with 4 to 7 days old flies.

\section{Oxidative stress resistance experiments}

We used paraquat (methyl viologen dichloride hydrate, ref. 75365-73-0, Sigma-Aldrich ${ }^{\circledR}$ ) to mimic oxidative stress. Oxidative stress was assessed by adding paraquat directly in the medium (10 $\mathrm{mM}$ ) before the cooling step and below $53^{\circ} \mathrm{C}$. The control experiment was made with the same medium but without paraquat. We used one isofemale line per locality (total of six) named Montpellier (France), Paris (France), Sapporo (Japan), Tokyo (Japan), Dayton (U.S.A.) and Watsonville (U.S.A.). We made three replicates per line and per sex, with ten flies per replicate. Survival was monitored every $24 \mathrm{~h}$. Flies were transferred into new vials every three to four days to limit microbial development.

\section{RT-qPCR analysis of Jheh genes}

We quantified the expression of the three Jheh genes (Jheh-1, Jheh-2 and Jheh-3) by RT-qPCR after induction of oxidative stress and in control condition. Adult males and females were exposed during $24 \mathrm{~h}$ to medium culture with $20 \mathrm{mM}$ of paraquat. After $24 \mathrm{~h}$ the flies were immediately dissected in PBS 1X solution (Gibco Thermo-Fisher) in order to extract carcasses for both sexes and eliminate germline tissues. We made three replicates per sex and treatment and used four flies per replicate.

RNA extraction was made using Direct-zol ${ }^{\mathrm{TM}}$-96 RNA Kits (Zymo Research), following the manufacturer recommendations and RNA was treated with DNAse. cDNA were obtained from 0.5 $\mu \mathrm{g}$ of RNA using SuperScript ${ }^{\mathrm{TM}}$ IV VILO ${ }^{\mathrm{TM}}$ Master Mix (Invitrogen). RT negative control was made with RNA but without the reverse transcriptase to control for genomic DNA contamination. CDNA were stored at $-80^{\circ} \mathrm{C}$ before the quantification step. Gene expression was then quantified by quantitative PCR and Rp49 was used as housekeeping gene. Primers were designed using the D. suzukii referenced genome (Table S1, (Chiu et al., 2013)). Their efficiency was between $91.1 \%$ to $97.2 \%$ (RP49: $91.6 \%$, Jheh-1: 97.2\%, Jheh-2: 95.2\%, Jheh-3: 91.1\%). $2 \mu \mathrm{l}$ of the cDNA sample were supplemented with $5 \mu \mathrm{L}$ of SsoADV Universal SYBR Green Supermix (BioRad) mix 2X, 0.3 
$33 \mu \mathrm{l}$ of each primer $(10 \mu \mathrm{M})$ and $2.4 \mu \mathrm{l}$ of pure water. We made technical duplicates for each sample.

34 PCR reactions were made in a BioRAd CFX-96 with a program consisted of an initial activation 35 of $95^{\circ} \mathrm{C}$ for 10 minutes and then 40 cycles each comprising 15 seconds at $95^{\circ} \mathrm{C}, 10$ seconds at $60^{\circ} \mathrm{C}$ and $72^{\circ} \mathrm{C}$.

\section{Genetic diversity of isofemale lines}

We sequenced intronic regions of Jheh gene cluster of the six lines used in this study. DNA was extracted individually from 10 females per line with the 96-Well Plate Animal Genomic DNA Miniprep kit (ref. BS437, Biobasic) following the manufacturer instructions. Primers were designed to flank the intronic regions for the three Jheh genes (Table S1) and Phusion high fidelity DNA Polymerase (2 U/ $\mu \mathrm{L})$ (F-530XL Thermofisher Scientific) was used to amplify sequences. The same PCR program was used for all primers pairs: $98^{\circ} \mathrm{C}$ for 10 minutes, followed by 40 cycles composed of 30 seconds at $98^{\circ} \mathrm{C}, 1$ minute at $56^{\circ} \mathrm{C}$ and 20 seconds at $72^{\circ} \mathrm{C}$ and a final elongation step for 1 minute at $72^{\circ} \mathrm{C}$. The sequencing of the two strands was done directly from the PCR product by BIOFIDAL sequencing company (Vaulx en Velin, France). Sequences were manually curated with CLC Main Workbench 8 software (Qiagen) before being aligneed with the Muscle program implemented in the workbench to generate haplotypes by line for each intron. MEGA X software was used to calculate pairwise comparison and nucleotide diversity using p-method option (Table S2-S3) (Kumar et al., 2018).

\section{Detection of Transposable elements and transcription factor binding sites}

We sequenced the intergenic regions of the Jheh gene cluster, plus the 5' and 3' regions of the cluster (Table S1). DNA was extracted from one female per population as described above. Classical PCR method was used with the following program, 10 minutes at $95^{\circ} \mathrm{C}$ followed by several cycles composed of 30 seconds at $95^{\circ} \mathrm{C}, 30$ seconds at $63^{\circ} \mathrm{C}, 3$ minutes at $72^{\circ} \mathrm{C}$ and a final elongation of 15 minutes at $72^{\circ} \mathrm{C}$. The number of cycles was 25 for the region before Jheh-1 and between Jheh-1 and Jheh-2, 35 cycles for the region between Jheh-2 and Jheh-3 and 30 cycles after Jheh-3. We identified TEs in the intergenic regions by a blast against a homemade data base of the TE sequences from the D. suzukii reference genome (Paris et al., 2020, Mérel et al., in prep.).

For TFBS (Table 1), we used conSite website to screen all TFBS from insect in our sequences (Sandelin et al., 2004). To complete our analysis, we used the TFBS obtained from VillanuevaCañas et al. (2019) and we extracted PFM (position frequency matrix) of the 14 TFBS from the JASPAR2018 database (v.1.1.1) (Parcy et al., 2017). Then, we used TFBSTools (v.1.22.0) package from R software (v. 3.6.0) to convert in PWM (position weight matrix), and then search 
66 on the 6 lines and the reference genome of D. suzukii (Paris et al., 2020; R Core Team, 2019;

67 Tan and Lenhard, 2016).

68

69

70

\section{Statistical analysis}

\section{Survival monitoring}

Survival data were analyzed using a linear mixed model with Imer function from Ime4 provided on $\mathrm{R}$ (v. 3.6.0) after a log transformation, confirmation of normality and homoscedasticity (Bates et al., 2015). This model was chosen after log-likelihood comparison between models (linear model with raw or log transformed data, survival model with a Weibull distribution).

We analyzed sexes separately to limit interaction terms, and focused on the effect of the treatment, the lines and their interaction. Biological replicates were added as random effect and we plotted exponential of the values and associated confidence interval on the Fig. S1. Those effects can be interpreted as multiplicative effect on the mean lifespan compared to the reference chosen here as the non-exposed group from Sapporo (e.g. the Sapporo reference is centered on 1 and the effect of paraquat 0.18 involves a survival time under paraquat for Sapporo of 0.18 or $18 \%$ of the survival time without paraquat).

\section{qPCR analysis}

RT-qPCR raw data were analyzed using $R$ and EasyqpcR library (1.21.0) for the quantification and normalization with RP49 (Sylvain, 2012). Data were analyzed separately for the three genes (Jheh-1 -2 and -3) and sex using a linear model (ANOVA2, Table S4) after log transformation to validate homoscedasticity and normality. Pairwise comparisons were made using a Tuckey test.

\section{RESULTS}

\section{D. suzukii wild type lines have significant differences in life span}

To investigate the influence of the genotypes from different geographical origins on the lifespan, we compared the invasive and native $D$. suzukii lines in control condition (Fig. 1A, Fig. S1 \& Table 2). The lifespan ranges from 31 to 55 days for females and from 25 to 45 days for males. For females we observed a strong genotype effect related to geographic location: the genotypes that lived the longest were those of Dayton and Paris (about 1.88-1.96 times more than Sapporo, Fig. S1). Sapporo, Tokyo, and Watsonville were not significantly different and with the lowest lifespan. For males, the four invasive genotypes from Europe and U.S.A had a higher lifespan than Sapporo. Tokyo was similar to Sapporo. 
As expected, exposure to paraquat reduced life span on average from 82 to $77 \%$ for

98

females and males (Fig. 1A, Fig. S1). The two lines with the best paraquat resistance in absolute value were still Dayton and Paris in both sexes (Fig. 1A and Table 2). We then wanted to have an estimate of paraquat sensitivity (i.e., the slope difference Fig.1 B) taking into account the longevity of each line by estimating the value of the interaction coefficients (i.e., the slope difference compared to Sapporo) in Table 2 and statistically tested in Fig. S1. Again, the effect was not similar between genotypes and sexes. For females, Paris was the line presenting significantly the highest sensitivity $(-0.87$, Table 2$)$ with a reduction of $28 \%$ of the life span compared to Sapporo (Fig. S1). For males, the reduction in life span was significantly the highest for Montpellier and Watsonville (-0.84 and -0.83 ) with a reduction from 34 and $32 \%$ by comparison with Sapporo. These results reveal a strong genotype-by-environment interaction in the response to oxidative stress and also a sex effect. It is interesting to note that despite the shorter life span of Japanese genotypes, and in particular of Sapporo in the absence of treatment, these genotypes were the most resistant to paraquat exposure, as shown by the lowest ratio of paraquat lifetime to control lifetime (Table 2).

\section{Jheh genes expression changes with the paraquat treatment}

To investigate the effect of paraquat-mediated oxidative stress on the gene expression level, we focused on Jheh gene cluster described as potentially involved in stress response in insects and mammals (Guio et al., 2014; Oesch et al., 2000). We quantified the level of expression of the Jheh genes (Jheh-1, Jheh-2 and Jheh-3) in adult males and females flies for the six genotypes described above (Fig. 2).

We observed strong differences between males and females. For males, gene expression was not significantly different between control and paraquat treatment for the six genotypes and for the three gene. In females, the effect of paraquat was different according to the gene and the genotype (Table S4). For Jheh-1 and Jheh-2, oxidative stress resulted in a significant increase of gene expression for the two French genotypes and the Tokyo genotype. On the contrary, the Sapporo genotype exhibited a significant reduction of Jheh-1 expression in presence of paraquat. For Jheh-3, we observed a downregulation of the gene expression only for the Sapporo genotype.

\section{Low Genetic diversity of lines in Jheh cluster}

To assess the levels of neutral genetic diversity within and between lines, we sequenced intronic regions for Jheh genes for each genotype (Fig. 3). As expected, the within-line polymorphism was very low (Table 3, Fig. S2), with the exception of Watsonville with 0.0792 for the first intron of Jheh-1. The number of haplotypes was also low (Table S2). The first intron of Jheh-2 presents 
31 the highest levels of diversity, contrasting with the other introns. This corresponds to a residual polymorphism that is still present in the lines despite the laboratory rearing.

Depending on the intronic regions we found between two to four haplotypes per genotype (Table S2). We computed the diversity between genotypes (global intronic nucleotide diversity $\pi$ ) using the most common haplotype for each intron, showing that on average these values are very small, with the highest value for Jheh-2.1 as mentioned above (Table S3).

Jheh harbour transcription factor binding sites (TFBS)

Transcription factor binding site (TFBS) are cis regulatory sequences that are recognized by transcription factors and modify gene expression. Several TFBS are known to be involved during oxidative response. We detected 9 of the 14 previous identified TFBS in the intergenic regions: HIF1A, br, cad, Cf2, Deaf1, CnC, dl, hb and Ubx (Fig. 3 \& 4, Table S5). Comparison of the number of TFBS between genotypes (Fig. 4) revealed several differences but not clear link with the changes in expression observed for the Jheh genes. For example, the Sapporo genotype which consistently showed a decrease in the expression of all three genes, did not appear to have a different specific TFBS. The two French genotypes which exhibited systematically an increase of expression after paraquat treatment appeared to have an increased number of putative TFBS. For example, the two French genotypes showed two Deaf1 motives when compared to the other genotypes upstream of TSS of the Jheh-1 gene. In the case of the Jheh-2 gene, the French genotypes presented a significant number of TFBS, with for example six TFBS for the Montpellier genotype (2Ubx, $2 \mathrm{hb}, \mathrm{CnC}$ and cad). In this region, no genotype showed the same pattern of TFBS and it was similar for Jheh-3.

Transposable elements do not affect Jheh gene expression

The presence of TE in the vicinity or within the Jheh cluster could impact the gene expression during oxidative stress because they could bring Antioxidant Response Element for transcription factors or by modifying chromatin state (Guio and González, 2015; Guio et al., 2014). Surprisingly, and even if $D$. suzukii harbors more than $30 \%$ of TEs, no full insertion was observed in the Jheh cluster indicating that we are probably in regions of high recombination. However, we did identify small pieces of TE that are quite conserved between the genotypes but no TFBS were detected in these sequences (Fig. 3, Table 4 \& S5). No obvious link seems to exist between gene expression and the presence of TE in the Jheh cluster. 
A growing body of literature suggests that responses to oxidative stress in Drosophila may be mediated by insertions of TEs, that in some cases could affect gene expression or the chromatin structure (Guio et al., 2014). In D. melanogaster, the Jheh gene cluster has been shown to be involved in the response to paraquat treatment and associated with local adaptation. Guio et al. (2014) compared D. melanogaster genotypes with and without Bari-Jheh TE insertion, and showed that, (i) TE insertion had a cost in the absence of stress, (ii) TE insertion confer increased survival in the presence of oxidative stress, (iii) TE insertion provides antioxidant response elements (AREs) that contribute to altered gene expression (Guio and González, 2015; Guio et al., 2014). In this study, we analyzed the expression of the Jheh gene cluster in several genotypes of $D$. suzukii to test whether the Jheh gene cluster is involved in the oxidative stress response and whether TEs could also be associated with alterations in gene expression.

We first measured the life span of flies without treatment. We showed that flies of the Japanese genotypes exhibited the shortest lifespan in both males and females. Surprisingly, these lines showed an increased resistance to oxidative stress. The French lines were more sensitive to paraquat than the American ones, although notable differences were observed between lines from the same continent. The negative association we observed between longevity and paraquat resistance had not been observed in previous work with $D$. melanogaster, in which the opposite association was observed (Finkel and Holbrook, 2000; Liguori et al., 2018). It could be argued that the use of paraquat in Europe has been banned since 2007, which could lead to a loosening of selection on genes related to paraquat resistance, as observed in other organisms (Campos et al., 2014; Shaw, 2000).

We then measured the expression of the Jheh genes previously reported to be involved in the oxidative response. Consistent with the literature of $D$. melanogaster, we found sex-specific responses to oxidative stress (Guio et al., 2014; Weber et al., 2012). For Jheh-1 and Jheh-2, we observed a significant effect of genotype and treatment, but only for females, contrary to what was reported in D. melanogaster. For Jheh-3, treatment and genotype effect were significant for both males and females. These differences in gene expression could not be associated with the presence of TEs insertions, since only partial sequences were present in the intergenic regions. The presence of various TFBS could contribute to the observed differences. We also quantified the polymorphism in our lines, which could be associated with differences in gene expression. We did not observe total homozygosity in the lines but genetic diversity was much lower than what is observed in natural populations of $D$. melanogaster. Lack et al. (2016) studied populations from several continents and measured values of nucleotide diversity of up to 0.401 within the population. For inbred DGRP (Drosophila Genetic Reference Panel) lines, the mean intronic diversity was $0.0076 \pm 0.008$, which is close to the values we observed (MacKay et al., 2012). It 
00 is therefore unlikely that the residual polymorphism in the Jheh gene region can explain the 01 differences in gene expression.

The striking result in our analysis is the similar pattern of changes in the expression of Jheh-1 and Jheh-2 in females of European genotypes, with an increase in expression, which was associated with lower resistance to oxidative stress, since these are the most sensitive genotypes. On the contrary, the Sapporo genotype systematically showed a reduction in the expression levels of the three genes, which could also be associated with increased resistance in the presence of paraquat, but this was not observed for the Tokyo genotype.

08

09

\section{Conclusion}

In conclusion, our work shows for the first time how various genotypes of $D$. suzukii respond to oxidative stress and suggests that populations found in invaded areas are more sensitive than Japanese populations, specially the French ones. We have also confirmed that the Jheh gene cluster is involved in the response to oxidative stress also in D. suzukii, independently of the presence of TE in intergenic regions. This work also suggests that the genetic background and probably trans regulatory sequences are involved in gene expression and stress response. Further phenotypic and genomic studies on natural populations are needed to better understand the success of invasive species such as $D$. suzukii.

\section{Acknowledgements}

21 We thanks to Vincent Mérel who produced the TEs annotation.

22 P. M. produced data, conceived and wrote the manuscript draft. C. V. \& P.G. designed experiments, edited the manuscript. A. J. calibrated experimental design. H. H. helped to q-PCR method and analysis.

\section{Funding}

Experimental procedures were supported by the ANR (grant SWING ANR to P.G. and C.V. grant ExHyb ANR to C.V.) and the Rovaltain foundation (EpiRip project).

\section{Author's informations}

30 Cristina Vieira: https://orcid.org/0000-0003-3414-3993

31 Pierre Marin: https://orcid.org/0000-0002-8304-138X 
Competing interests

35

36

The authors declare that they have no competing interests.

Bates, D., Mächler, M., Bolker, B. M. and Walker, S. C. (2015). Fitting linear mixed-effects models using Ime4. Journal of Statistical Software 67,.

Beldade, P., Mateus, A. R. A. and Keller, R. A. (2011). Evolution and molecular mechanisms of adaptive developmental plasticity. Molecular Ecology 20, 1347-1363.

Bus J S and Gibson J E (1984). Paraquat: model for oxidant-initiated toxicity. Environmental Health Perspectives 55, 37-46.

CABI (2020). CABI. Invasive Species Compendium. Wallingford, UK: CAB International. CABI.

Campos, M. R., Rodrigues, A. R. S., Silva, W. M., Silva, T. B. M., Silva, V. R. F., Guedes, R. N. C. and Siqueira, H. A. A. (2014). Spinosad and the Tomato Borer Tuta absoluta: A Bioinsecticide, an Invasive Pest Threat, and High Insecticide Resistance. PLoS One 9,.

Chiu, J. C., Jiang, X., Zhao, L., Hamm, C. A., Cridland, J. M., Saelao, P., Hamby, K. A., Lee, E. K., Kwok, R. S., Zhang, G., et al. (2013). Genome of Drosophila suzukii, the Spotted Wing Drosophila. G3: Genes, Genomes, Genetics 3, 2257-2271.

Dalton, D. T., Walton, V. M., Shearer, P. W., Walsh, D. B., Caprile, J. and Isaacs, R. (2011). Laboratory survival of Drosophila suzukii under simulated winter conditions of the Pacific Northwest and seasonal field trapping in five primary regions of small and stone fruit production in the United States. Pest Management Science 67, 1368-1374.

David, J. R., Gibert, P., Legout, H., Pétavy, G., Capy, P. and Moreteau, B. (2005). Isofemale lines in Drosophila: an empirical approach to quantitative trait analysis in natural populations. Heredity 94, 3-12.

Estoup, A., Ravign, V., Hufbauer, R., Vitalis, R., Gautier, M. and Facon, B. (2016). Is There A Genetic Paradox of Biological Invasion? Annual Review of Ecology Evolution and Systematics 47, 51-72.

Finkel, T. and Holbrook, N. J. (2000). Oxidants, oxidative stress and the biology of ageing. Nature 408, 239-247.

Flatt, T. and Kawecki, T. J. (2007). Juvenile Hormone as a Regulator of the Trade-Off Between Reproduction and Life Span in Drosophila Melanogaster. Evolution 61, 1980-1991.

Fraimout, A., Debat, V., Fellous, S., Hufbauer, R. A., Foucaud, J., Pudlo, P., Marin, J.-M., Price, D. K., Cattel, J., Chen, X., et al. (2017). Deciphering the routes of invasion of Drosophila suzukii by means of ABC random forest. Molecular biology and evolution 34, 980-996.

Ghalambor, C. K., Hoke, K. L., Ruell, E. W., Fischer, E. K., Reznick, D. N. and Hughes, K. a. (2015). Non-adaptive plasticity potentiates rapid adaptive evolution of gene expression in nature. Nature 525, 372-375.

Gibert, P., Hill, M., Pascual, M., Plantamp, C., Terblanche, J. S., Yassin, A. and Sgrò, C. M. (2016). Drosophila as models to understand the adaptive process during invasion. Biological Invasions 18, 1089-1103. 
Guio, L. and González, J. (2015). The Dominance Effect of the Adaptive Transposable Element Insertion Bari-Jheh Depends on the Genetic Background. Genome Biol Evol 7, 1260-1266.

Guio, L., Barrón, M. G. and González, J. (2014). The transposable element Bari-Jheh mediates oxidative stress response in Drosophila. Molecular Ecology 23, 2020-2030.

Kumar, S., Stecher, G., Li, M., Knyaz, C. and Tamura, K. (2018). MEGA X: Molecular Evolutionary Genetics Analysis across Computing Platforms. Mol Biol Evol 35, 15471549.

Lack, J. B., Lange, J. D., Tang, A. B., Corbett-Detig, R. B. and Pool, J. E. (2016). A Thousand Fly Genomes: An Expanded Drosophila Genome Nexus. bioRxiv 063537.

Lavrinienko, A., Kesäniemi, J., Watts, P. C., Serga, S., Pascual, M., Mestres, F. and Kozeretska, I. (2017). First record of the invasive pest Drosophila suzukii in Ukraine indicates multiple sources of invasion. Journal of Pest Science 90, 421-429.

Liguori, I., Russo, G., Curcio, F., Bulli, G., Aran, L., Della-Morte, D., Gargiulo, G., Testa, G., Cacciatore, F., Bonaduce, D., et al. (2018). Oxidative stress, aging, and diseases. Dove Medical Press Ltd.

MacKay, T. F. C., Richards, S., Stone, E. A., Barbadilla, A., Ayroles, J. F., Zhu, D., Casillas, S., Han, Y., Magwire, M. M., Cridland, J. M., et al. (2012). The Drosophila melanogaster Genetic Reference Panel. Nature 482, 173-178vi.

Marin, P., Genitoni, J., Barloy, D., Maury, S., Gibert, P., Ghalambor, C. K. and Vieira, C. (2019). Biological invasion: The influence of the hidden side of the (epi)genome. Functional Ecology 34, 385-400.

Oesch, F., Herrero, M. E., Hengstler, J. G., Lohmann, M. and Arand, M. (2000). Metabolic Detoxification: Implications for Thresholds. Toxicologic Pathology 28, 382-387.

Parcy, F., Khan, A., Baranasic, D., Kulkarni, S. R., Stigliani, A., van der Lee, R., Vandepoele, K., Gheorghe, M., Lenhard, B., Tan, G., et al. (2017). JASPAR 2018: update of the open-access database of transcription factor binding profiles and its web framework. Nucleic Acids Research 46, D260-D266.

Paris, M., Boyer, R., Jaenichen, R., Wolf, J., Karageorgi, M., Green, J., Cagnon, M., Parinello, H., Estoup, A., Gautier, M., et al. (2020). Near-chromosome level genome assembly of the fruit pest Drosophila suzukii using long-read sequencing. bioRxiv 2020.01.02.892844.

R Core Team (2019). R: A Language and Environment for Statistical Computing.

Rzezniczak, T. Z., Douglas, L. A., Watterson, J. H. and Merritt, T. J. S. (2011). Paraquat administration in Drosophila for use in metabolic studies of oxidative stress. Analytical Biochemistry 419, 345-347.

Sandelin, A., Wasserman, W. W. and Lenhard, B. (2004). ConSite: web-based prediction of regulatory elements using cross-species comparison. Nucleic Acids Res 32, W249W252.

Sessegolo, C., Burlet, N. and Haudry, A. (2016). Strong phylogenetic inertia on genome size and transposable element content among 26 species of flies. Biology Letters 12, 20160407. 
Shaw, M. W. (2000). Models of the Effects of Dose Heterogeneity and Escape on Selection Pressure for Pesticide Resistance. Phytopathology ${ }^{T M}$ 90, 333-339.

Stapley, J., Santure, A. W. and Dennis, S. R. (2015). Transposable elements as agents of rapid adaptation may explain the genetic paradox of invasive species. Molecular Ecology 24, 2241-2252.

Sylvain, L. P. (2012). EasyqpcR: EasyqpcR for low-throughput real-time quantitative PCR data analysis. Bioconductor version: Release (3.10).

Tan, G. and Lenhard, B. (2016). TFBSTools: an R/Bioconductor package for transcription factor binding site analysis. Bioinformatics 32, 1555-1556.

Tsai, W.-T. (2018). Status of herbicide use, regulatory management and case study of paraquat in Taiwan. Environment, Development and Sustainability.

Vermeulen, C. J., Van De Zande, L. and Bijlsma, R. (2005). Resistance to Oxidative Stress Induced by Paraquat Correlates Well with Both Decreased and Increased Lifespan in Drosophila melanogaster. Biogerontology 6, 387-395.

Villanueva-Cañas, J. L., Horvath, V., Aguilera, L. and González, J. (2019). Diverse families of transposable elements affect the transcriptional regulation of stress-response genes in Drosophila melanogaster. Nucleic Acids Res 47, 6842-6857.

Weber, A. L., Khan, G. F., Magwire, M. M., Tabor, C. L., Mackay, T. F. C. and Anholt, R. R. H. (2012). Genome-wide association analysis of oxidative stress resistance in drosophila melanogaster. PLOS ONE 7,.

\section{List of the figures}

Fig. 1. Mean ( \pm SD) of survival time (days) of $D$. suzukii genotypes (A) and reaction norm (log of the mean) (B). (A) mean values under control and paraquat condition for females (pink) and males (blue) with associated SD. (B) reaction norm between treatments (control and paraquat) for both females and males for the six genotypes using log transformed mean value. The slope differences between the curves highlight the difference of sensitivity between genotypes.

Fig. 2. Jheh gene expression (Jheh-1, -2, -3) after normalization by Rp49 in control (green) and paraquat (red) conditions for females on the left and males on the right.

Fig. 3. Representation of the Jheh gene cluster on the reference genome and the relative position on the other six genotypes. The blue squares represent the exons and the blue lines the intronic regions. Red triangles represent TE detected in the intergenic regions and TFBS are indicated by vertical lines. The scale is shown below the figure in base pairs.

Fig. 4. TFBS detected in the four intergenic regions of the Jheh gene cluster in the reference genome and in the six genotypes of $\boldsymbol{D}$. suzukii. Of the 14 TFBS examined, 8 had at least one positive result. The intergenic regions are upstream Jheh-1(CG18190-Jheh-1), between Jheh-1 and -2 (Jheh1-Jheh2), between Jheh2 and -3 (Jheh2-Jheh3) downstream of Jheh-3 (Jheh3-CG43069). 


\section{List of the tables}

Table 1. Transcription factor analyzed with the PWM matrix ID from JASPAR2018. Mainly matrix come from D. melanogaster model, but several as HSF, HIF1 and XBP1 come from human, while MTF1 come from mice.

Table 2. Mean ( $(\mathrm{SD})$ survival time (days) for male and female lines of $\mathrm{D}$. suzukii under control and paraquat conditions. Sensitivity represents the exponential of the interaction values in the model (i.e., the difference in slope between the Sapporo reference and the other genotypes, see Figure S1). * indicate a significant difference with the reference $(p-v a l u e<0.05)$.

Table 3. Within-line diversity (pi) for the six genotypes of D. suzukii for the seven sequenced intronic regions. The mean diversity per intron was calculated using the most common sequence of the six genotypes.

Table 4. Size differences (bp) between the six genotypes and the reference genome. TE insertions are indicated by their size or abs if they are absent.

\section{List of supplementary figures}

Fig. S1. Representation of the parameters estimated by the model for treatment, genotypes and interactions for females (left) and males (right). Values were transformed exponentially to be interpreted as a multiplicator effect. The vertical line corresponds to the reference. Associated $p$-values are greater than 0.05 when the confidence interval includes the vertical line.

Fig. S2. Distribution of the between genotype (blue) and within genotype (pink) genetic diversity using pi values for all intronic regions.

\section{List of supplementary tables}

\section{Table S1. Primers used for the PCR experiments.}

Table S2. Genotypes of $\boldsymbol{D}$. suzukii with the number of haplotypes obtained. The length of the sequence corresponds to the size of the amplified fragment used to calculate the average diversity per population per intron. The mean diversity was calculated as the average between the most common haplotypes of the 6 lines.

Table S3. Pairwise genetic distance between genotypes. Bold values represent genetic diversity within lines.

Table S4. Summary of the ANOVA 2 by gene and sex. 
87 Table S5. TFBS and TE detected in all six genotypes and the reference genome of $D$.

88 suzukii. We screened TFBS in the intergenic regions before, between and after the Jheh genes.

89 The names of the transcription factors (TF) and transposable elements (TE) are given with their

90 positions in the sequence (beginning and end).

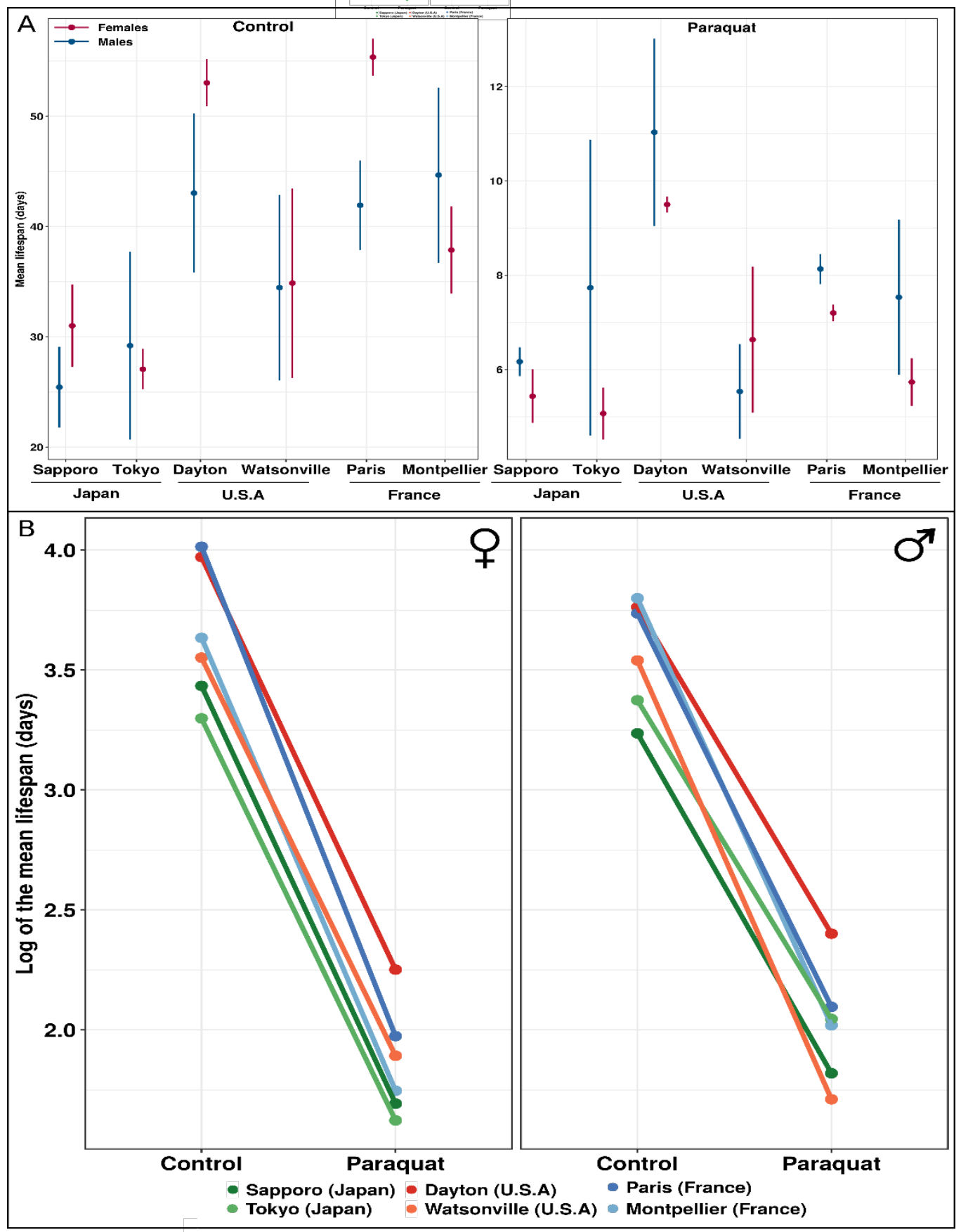




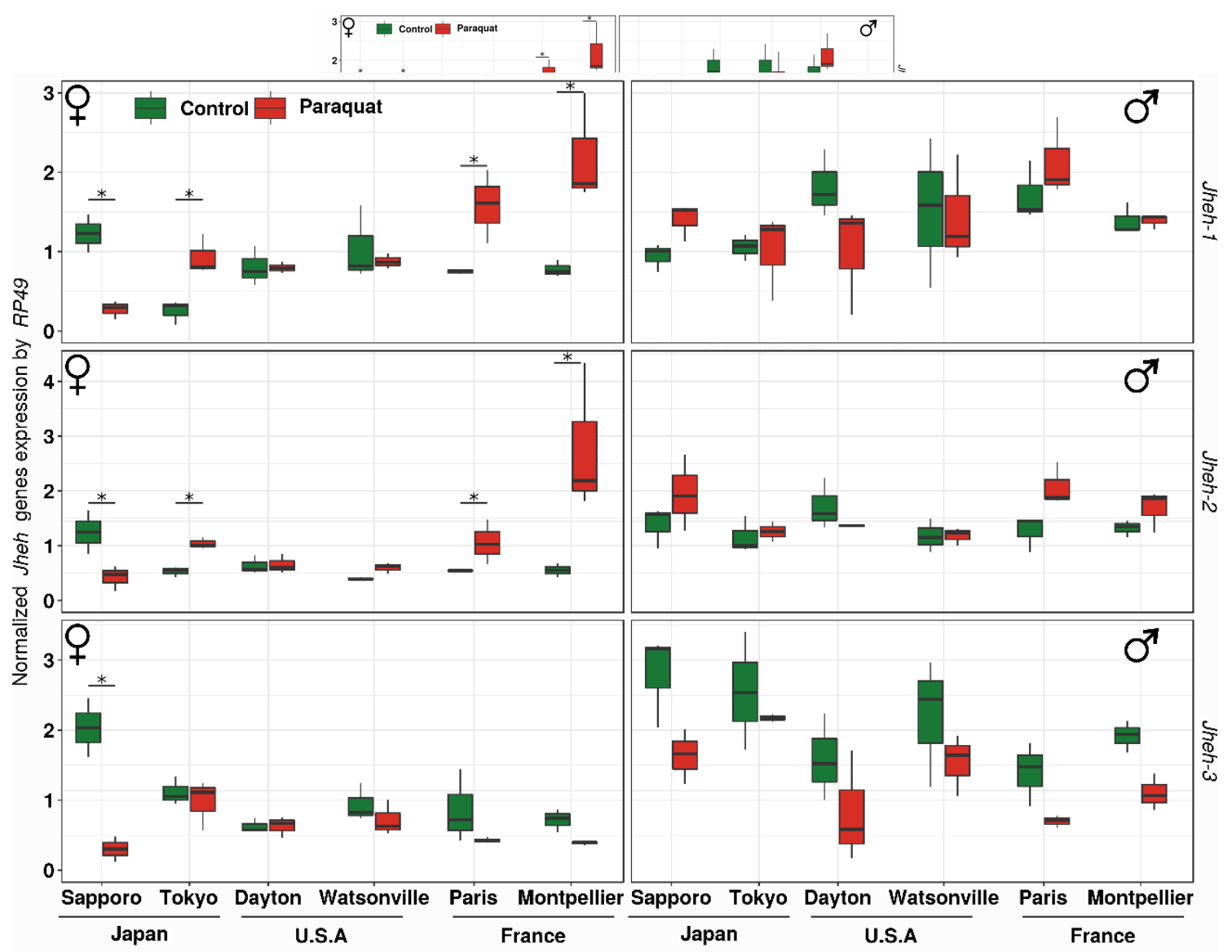

Figure 2

05

06

07

08 


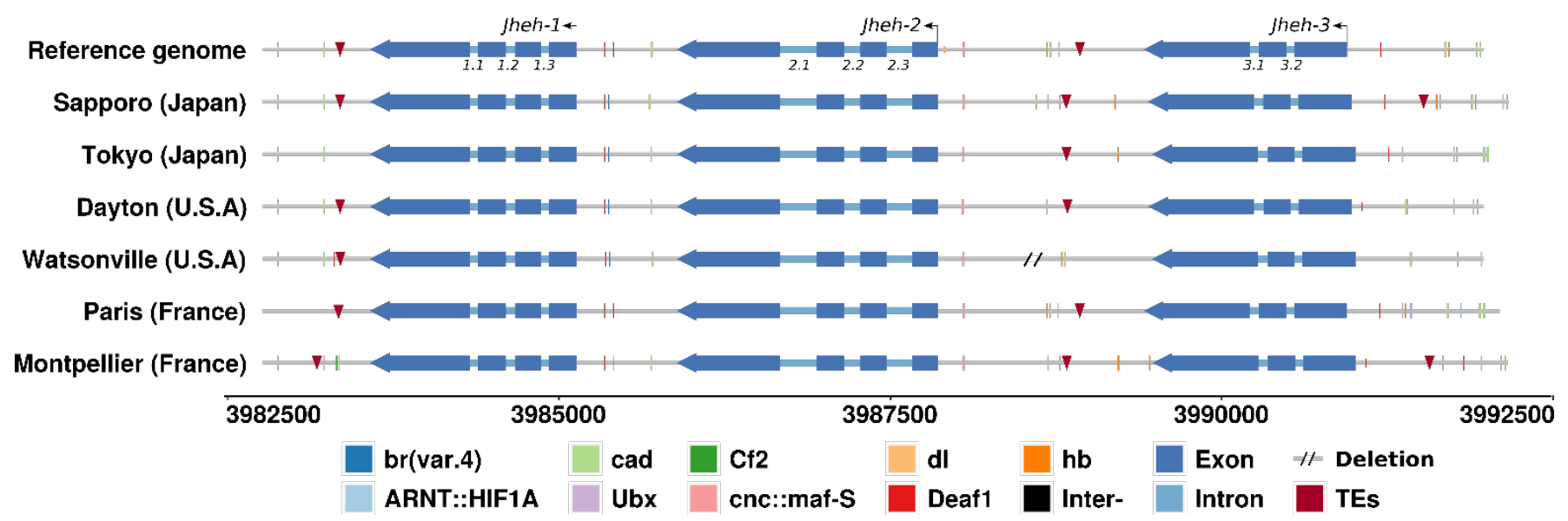

13 Figure 3

14

15

16

17

18 


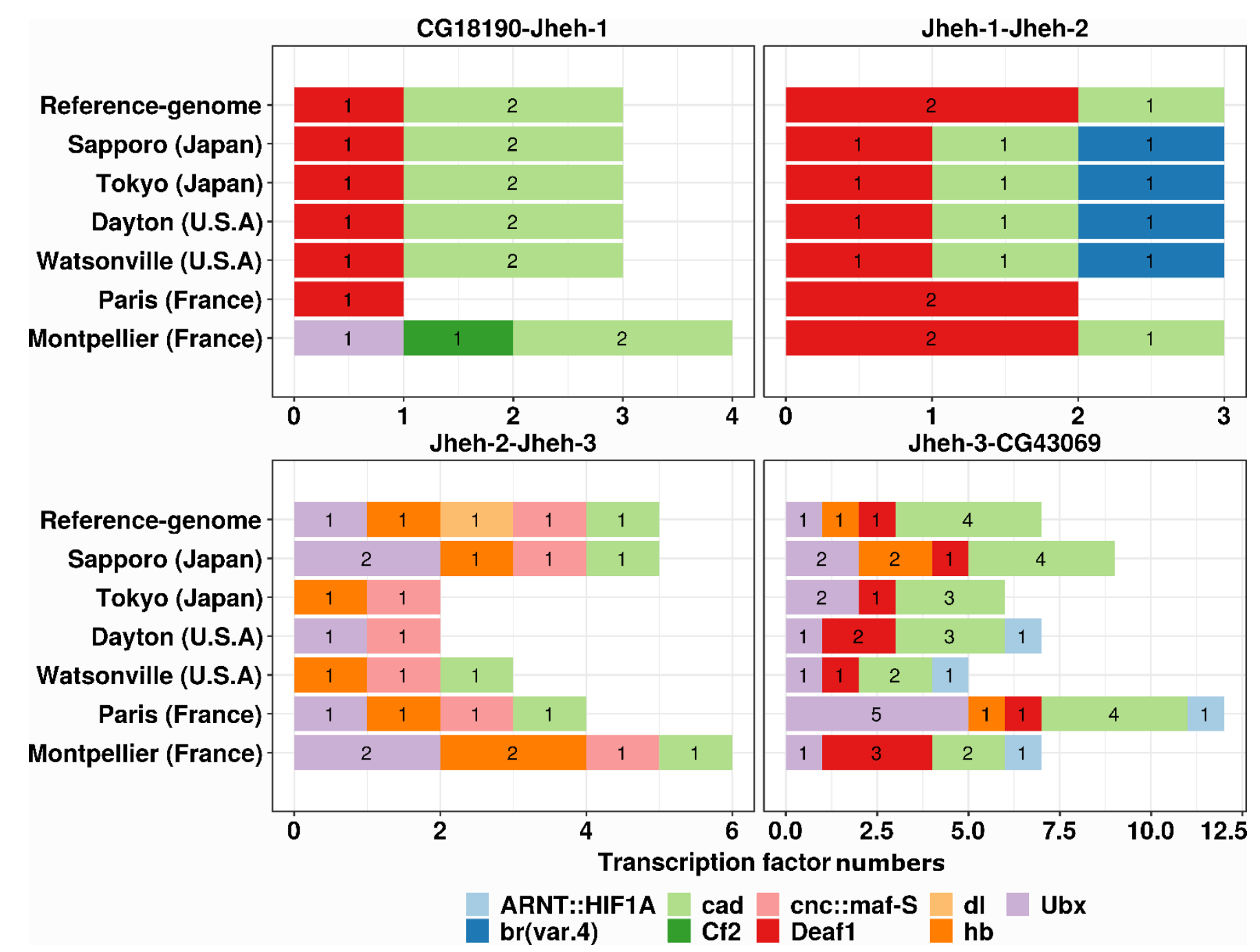

\section{$23 \quad$ Figure 4}


38 Table 1. Transcription factor analyzed with the PWM matrix ID from JASPAR2018. Mainly

39 matrix come from $D$. melanogaster model, but several as HSF, HIF1 and XBP1 come from human, 40 while MTF1 come from mice.

\begin{tabular}{|c|c|c|c|}
\hline Trancription factors & PWM ID & Species & Origin \\
\hline HSF (heat shock factor) & MA0486.2 & $\begin{array}{l}\text { Homo } \\
\text { sapiens }\end{array}$ & \multirow{9}{*}{$\begin{array}{l}\text { From Villanueva- } \\
\text { Cañas et al. (2019) }\end{array}$} \\
\hline HIF1 (hypoxia inducible factor) & MA0259.1 & $\begin{array}{l}\text { Homo } \\
\text { sapiens }\end{array}$ & \\
\hline DL (Dorsal) & MA0022.1 & $\begin{array}{c}D . \\
\text { melanogaster }\end{array}$ & \\
\hline $\begin{array}{l}\text { MTF1 (Metal response element- } \\
\text { binding Transcription Factor-1) }\end{array}$ & PB0044.1 & $\begin{array}{c}\text { Mus } \\
\text { musculus }\end{array}$ & \\
\hline $\begin{array}{r}\text { DEAF1 (Deformed epidermal } \\
\text { autoregulatory factor-1) }\end{array}$ & MA0185.1 & $\begin{array}{c}D . \\
\text { melanogaster }\end{array}$ & \\
\hline CAD (caudal) & MA0216.2 & $\begin{array}{c}D . \\
\text { melanogaster }\end{array}$ & \\
\hline NUB (nubbin) & MA0197.2 & $\begin{array}{c}D . \\
\text { melanogaster }\end{array}$ & \\
\hline XBP1 (X box binding protein-1) & MA0844.1 & $\begin{array}{l}\text { Homo } \\
\text { sapiens }\end{array}$ & \\
\hline CnC (cap-n-collar) & MA0530.1 & $\begin{array}{c}D . \\
\text { melanogaster }\end{array}$ & \\
\hline Br(var4) (broad complex 4) & MA0013.1 & $\begin{array}{c}D . \\
\text { melanogaster }\end{array}$ & \multirow{5}{*}{$\begin{array}{l}\text { From conSite website } \\
\text { (Sandelin et al., 2004) }\end{array}$} \\
\hline $\mathrm{Hb}$ (hunchbak) & MA0049.1 & $\begin{array}{c}D . \\
\text { melanogaster }\end{array}$ & \\
\hline Ubx (Ultrabithorax) & MA0094.2 & $\begin{array}{c}D . \\
\text { melanogaster }\end{array}$ & \\
\hline Cf2 (Chorion factor 2) & MA0015.1 & $\begin{array}{c}D . \\
\text { melanogaster }\end{array}$ & \\
\hline Snail (sna) & MA0086.2 & $\begin{array}{c}D . \\
\text { melanogaster }\end{array}$ & \\
\hline
\end{tabular}


44 Table 2. Mean (士SD) survival time (days) for male and female lines of D. suzukii under 45 control and paraquat conditions. Sensitivity represents the exponential of the interaction values 46 in the model (i.e., the difference in slope between the Sapporo reference and the other genotypes, 47 see Figure S1). * indicate a significant difference with the reference ( $p$-value $<0.05)$.

\begin{tabular}{r|cc|c|ccc}
\multicolumn{5}{c|}{ Females } & \multicolumn{3}{c}{ Males } \\
\hline \multicolumn{1}{c|}{ Lines } & Control & Paraquat & sensitivity & Control & Paraquat & sensitivity \\
\hline Sapporo (Japan) & $31 \pm 13.3$ & $5.4 \pm 2.3$ & 1.0 & $25.4 \pm 5.9$ & $6.2 \pm 2.1$ & 1.0 \\
\hline Tokyo (Japan) & $27.1 \pm 9.1$ & $5.1 \pm 1.9$ & 1.06 & $29.2 \pm 11.5$ & $7.7 \pm 4.9$ & 1.02 \\
\hline Dayton (U.S.A) & $53 \pm 8.4$ & $9.5 \pm 3$ & 0.98 & $42.8 \pm 16.3$ & $11 \pm 4.1$ & 1.23 \\
\hline Watsonville (U.S.A) & $34.9 \pm 13.8$ & $6.6 \pm 2.3$ & 1.13 & $34.5 \pm 11.2$ & $5.5 \pm 2.1$ & $0.68^{*}$ \\
\hline Paris (France) & $55.4 \pm 9.4$ & $7.2 \pm 1.8$ & $0.72^{*}$ & $41.9 \pm 14.8$ & $8.1 \pm 2.8$ & 0.9 \\
\hline Montpellier (France) & $37.9 \pm 8.4$ & $5.7 \pm 2.2$ & 0.83 & $44.7 \pm 12.2$ & $7.5 \pm 3.8$ & $0.66^{*}$ \\
\hline
\end{tabular}


Table 3 Within-line diversity (pi) for the six genotypes of D. suzukii for the seven sequenced intronic regions. The mean diversity per intron was calculated using the most common sequence of the six 72 genotypes.

Jheh-1.1 Jheh-1.2 Jheh-1.3 Jheh-2.1 Jheh-2.2 Jheh-2.3 Jheh-3.2

\begin{tabular}{rlllllll}
\hline Paris & 0.0000 & 0.0000 & 0.0000 & 0.0460 & 0.0000 & 0.0000 & 0.0000 \\
\hline Montpellier & 0.0000 & 0.0169 & 0.0000 & 0.0502 & 0.0081 & 0.0000 & 0.0339 \\
\hline Sapporo & 0.0000 & 0.0000 & 0.0396 & 0.0546 & 0.0000 & 0.0000 & 0.0000 \\
\hline Tokyo & 0.0000 & 0.0000 & 0.0000 & 0.0324 & 0.0000 & 0.0144 & 0.0113 \\
\hline Dayton & 0.0000 & 0.0000 & 0.0000 & 0.0449 & 0.0000 & 0.0096 & 0.0000 \\
\hline Watsonville & 0.0792 & 0.0000 & 0.0198 & 0.0466 & 0.0000 & 0.0000 & 0.0000 \\
\hline $\begin{array}{r}\text { Mean pi } \\
\text { diversity }\end{array}$ & 0.0070 & 0.0080 & 0.0177 & 0.0390 & 0.0214 & 0.0333 & 0.0209
\end{tabular}


98 Table 4. Size differences (bp) between the six genotypes and the reference genome. TE

99 insertions are indicated by their size or abs if they are absent.

\begin{tabular}{|c|c|c|c|c|c|c|c|c|}
\hline & & $\begin{array}{l}\text { expected } \\
\text { size } \\
\text { (reference } \\
\text { genome) }\end{array}$ & $\begin{array}{l}\text { Sapporo } \\
\text { (Japan) }\end{array}$ & $\begin{array}{l}\text { Tokyo } \\
\text { (Japan) }\end{array}$ & $\begin{array}{l}\text { Dayton } \\
\text { (U.S.A) }\end{array}$ & $\begin{array}{c}\text { Watsonville } \\
\text { (U.S.A) }\end{array}$ & $\begin{array}{c}\text { Paris } \\
\text { (France) }\end{array}$ & $\begin{array}{c}\text { Montpellier } \\
\text { (France) }\end{array}$ \\
\hline \multirow[b]{2}{*}{ X-Jheh1 } & Size & 809 & 0 & -2 & 0 & +1 & 0 & +12 \\
\hline & $\begin{array}{r}\text { TE } \\
\text { insertion }\end{array}$ & 82 & 82 & abs & 82 & 82 & 82 & abs \\
\hline \multirow[b]{2}{*}{ Jheh1/jheh2 } & Size & 756 & -17 & -6 & -2 & +2 & +1 & +7 \\
\hline & $\begin{array}{r}T E \\
\text { insertion }\end{array}$ & abs & abs & abs & abs & abs & abs & abs \\
\hline \multirow[b]{2}{*}{ Jheh2/Jheh3 } & Size & 1541 & +31 & -64 & +35 & -297 & -1 & +66 \\
\hline & $\begin{array}{r}\mathrm{TE} \\
\text { insertion }\end{array}$ & 41 & 48 & 49 & 91 & abs & 41 & 49 \\
\hline \multirow[b]{2}{*}{ Jheh3-Y } & Size & 1021 & +171 & -8 & +58 & -55 & +29 & +122 \\
\hline & $\begin{array}{r}\text { TE } \\
\text { insertion }\end{array}$ & abs & 58 & abs & abs & abs & abs & 36 \\
\hline
\end{tabular}

00

01

02

03

04

05

06

07 


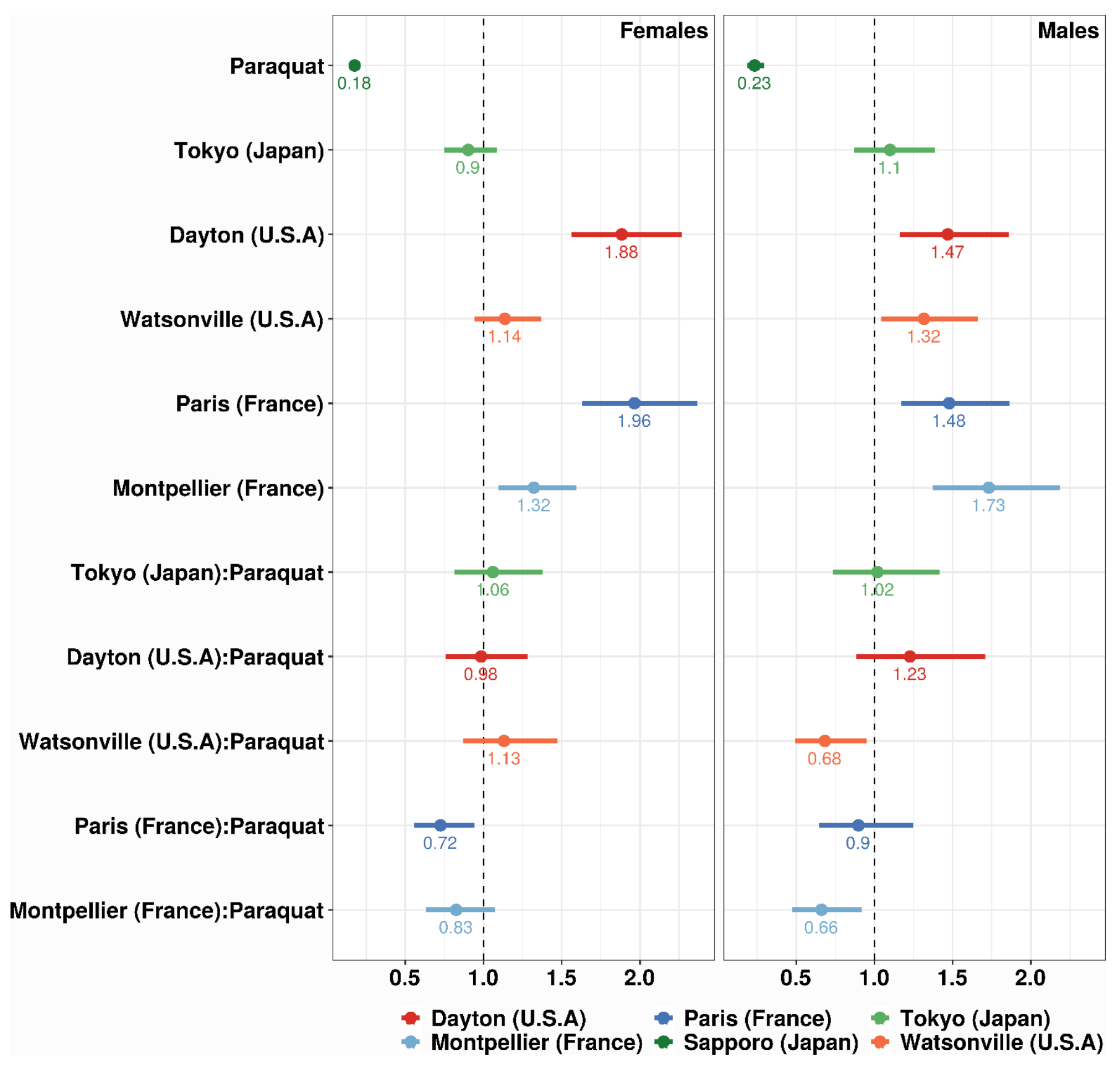

11 Fig. S1. Representation of the parameters estimated by the model for treatment, genotypes and 12 interactions for females (left) and males (right). Values were transformed exponentially to be 13 interpreted as a multiplicator effect. The vertical line corresponds to the reference. Associated p-values 14 are greater than 0.05 when the confidence interval includes the vertical line. 


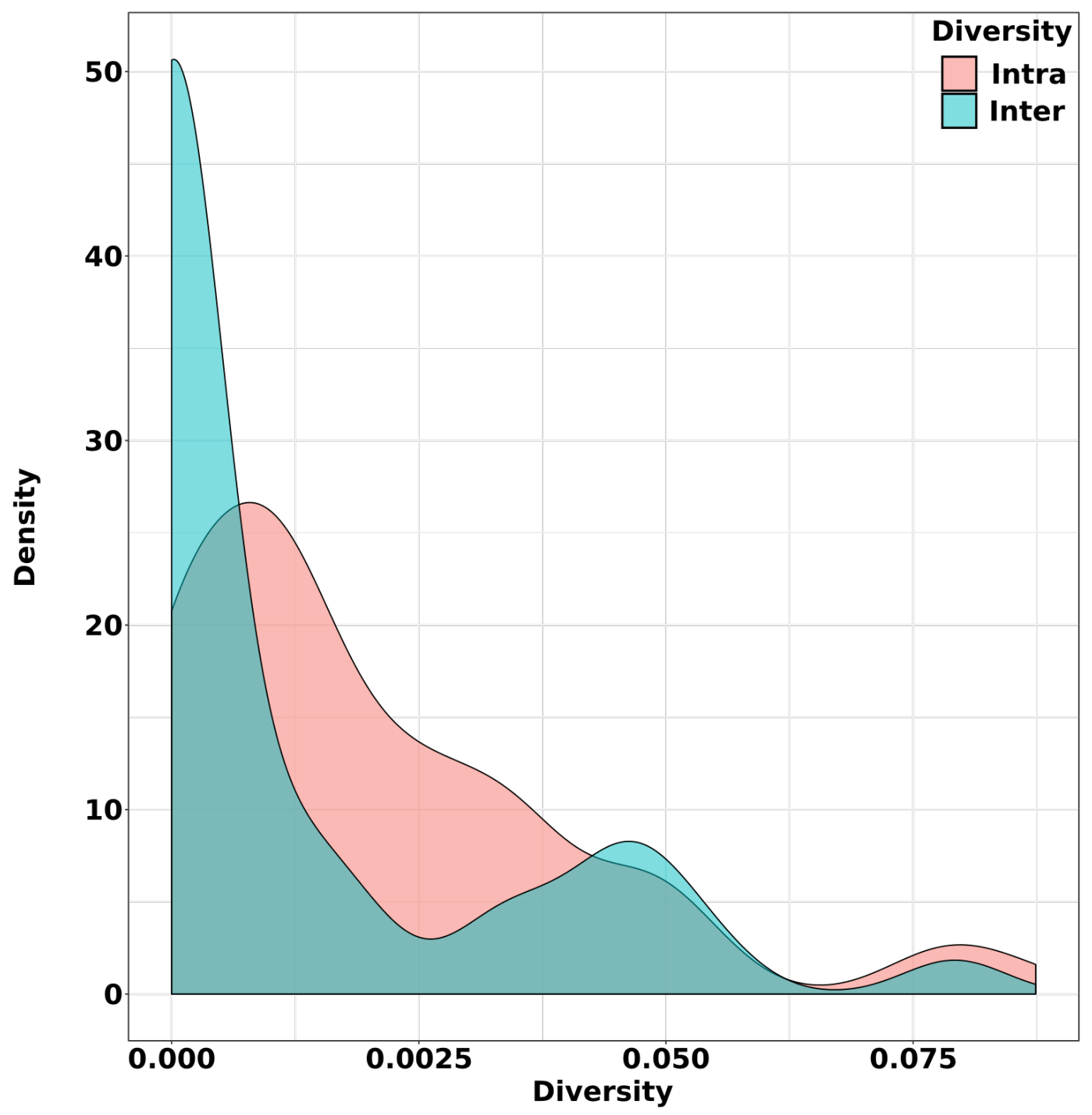

18 Fig. S2. Distribution of the between genotype (blue) and within genotype (pink) genetic diversity using 19 pi values for all intronic regions. 
31

\begin{tabular}{|c|c|}
\hline Name & Sequence \\
\hline Jheh-1 & $\begin{array}{l}\text { Forward: GAGCAACCTGGACAAGAACAAC } \\
\text { Reverse: TATCCCAAGCGCTGCATAAG }\end{array}$ \\
\hline Jheh-2 & $\begin{array}{l}\text { Forward: AGAAGCTGGACCACTACCAAAC } \\
\text { Reverse: AGAACCTTCTTGGGCTTCTGG }\end{array}$ \\
\hline Jheh-3 & $\begin{array}{l}\text { Forward: AGTACGCTTTTGAGGTCGTG } \\
\text { Reverse: AGACGCAGCATCAAGTTTCG }\end{array}$ \\
\hline$R P 49$ & $\begin{array}{l}\text { Forward: CCGCTTCAAGGGACAGTATC } \\
\text { Reverse: GACGATCTCCTTGCGCTTCT }\end{array}$ \\
\hline DS10_00005800-Jheh-1 & $\begin{array}{l}\text { Forward: GTGTCCCTGGACCATGTTGT } \\
\text { Reverse: GGAGGACACTTTGCGGCTAT }\end{array}$ \\
\hline Jheh-1-Jheh-2 & $\begin{array}{l}\text { Forward: GCCAATGGCCAGTACACAGA } \\
\text { Reverse: GCCCCAGAAGCTGTACGATG }\end{array}$ \\
\hline Jheh-2-Jheh-3 & $\begin{array}{l}\text { Forward: GCAAAGTGAGCATGATTTGGC } \\
\text { Reverse: CAACCCTGTGAACCGAGCTA }\end{array}$ \\
\hline DS10_0005804-Jheh-3 & $\begin{array}{l}\text { Forward: GCAATTAGCTCCCACTCGGT } \\
\text { Reverse: CGTGACACTGCAGTTTATGGC }\end{array}$ \\
\hline Jheh-1_intr1 & $\begin{array}{l}\text { Forward: GAGCGGATCCTAGACCCTTC } \\
\text { Reverse: GCTGGTCGGAGGTAAGTTGT }\end{array}$ \\
\hline Jheh-1_intr2 & $\begin{array}{l}\text { Forward: AAGAAAGTGCATGCGTAGCC } \\
\text { Reverse: TGGCAGTTCAACCACTTCAC }\end{array}$ \\
\hline Jheh-1_intr3 & $\begin{array}{l}\text { Forward: ATTGAGGCGGCTCTTTAGGT } \\
\text { Reverse: CGGAGGTGATAAACAACAAACTT }\end{array}$ \\
\hline Jheh-2_intr1 & $\begin{array}{l}\text { Forward: GAGGCCTGGAATTGGAAAAT } \\
\text { Reverse: TCTCGAGGGAATAAGAGGTTCA }\end{array}$ \\
\hline Jheh-2_intr2 & $\begin{array}{l}\text { Forward: CGGCTTGGCATGAATAAAGT } \\
\text { Reverse: ACGGAGATCCAGGGGTAAGT }\end{array}$ \\
\hline Jheh-2_intr3 & $\begin{array}{l}\text { Forward: CCTCAATTACCTGTGGGGTAAA } \\
\text { Reverse: CCCGAGGTAAGCTATGTTTCA }\end{array}$ \\
\hline Jheh-3_intr2 & $\begin{array}{l}\text { Forward: GCCTTCTCGTGAACGTAGTGA } \\
\text { Reverse: CAAGCAGTACACGACCGAGA }\end{array}$ \\
\hline
\end{tabular}


38 Table S2. Genotypes of $\boldsymbol{D}$. suzukii with the number of haplotypes obtained. The length of 39 the sequence corresponds to the size of the amplified fragment used to calculate the average 40 diversity per population per intron. The mean diversity was calculated as the average between 41 the most common haplotypes of the 6 lines.

42

\begin{tabular}{|c|c|c|c|c|}
\hline \multirow[b]{2}{*}{ Lineage } & & \multicolumn{3}{|c|}{ Jheh-1 intron 1} \\
\hline & $\begin{array}{c}\text { \# of } \\
\text { haplotypes }\end{array}$ & \# of flies & $\begin{array}{l}\text { Size of the } \\
\text { alignment }\end{array}$ & Mean diversity \\
\hline Paris (France) & 1 & 6 & \multirow{6}{*}{$97 \mathrm{pb}$} & \multirow{6}{*}{0.0070} \\
\hline $\begin{array}{r}\text { Montpellier } \\
\text { (France) }\end{array}$ & 1 & 10 & & \\
\hline Sapporo Japan) & 1 & 6 & & \\
\hline Tokyo (Japan) & 1 & 10 & & \\
\hline Dayton (U.S.A) & 1 & 10 & & \\
\hline \multirow[t]{3}{*}{$\begin{array}{r}\text { Watsonville } \\
(\text { U.S.A) }\end{array}$} & 2 & $7-2$ & & \\
\hline & & \multicolumn{3}{|c|}{ Jheh-1 intron 2} \\
\hline & $\mathrm{N}$ haplotype & $\mathrm{N}$ & Alignment & Mean diversity \\
\hline Paris (France) & 1 & 10 & \multirow{6}{*}{$119 p b$} & \multirow{6}{*}{0.0080} \\
\hline $\begin{array}{r}\text { Montpellier } \\
\text { (France) }\end{array}$ & 2 & $4-3$ & & \\
\hline Sapporo Japan) & 1 & 10 & & \\
\hline Tokyo (Japan) & 1 & 10 & & \\
\hline Dayton (U.S.A) & 1 & 10 & & \\
\hline \multirow[t]{3}{*}{$\begin{array}{r}\text { Watsonville } \\
(\text { U.S.A })\end{array}$} & 1 & 10 & & \\
\hline & & \multicolumn{3}{|c|}{ Jheh-1 intron 3} \\
\hline & $\mathrm{N}$ haplotype & $\mathrm{N}$ & Alignment & Mean diversity \\
\hline
\end{tabular}




\begin{tabular}{|c|c|c|c|c|}
\hline Paris (France) & 1 & 10 & \multirow{6}{*}{$133 p b$} & \multirow{6}{*}{0.0177} \\
\hline $\begin{array}{r}\text { Montpellier } \\
\text { (France) }\end{array}$ & 1 & 10 & & \\
\hline Sapporo Japan) & 2 & $7-2$ & & \\
\hline Tokyo (Japan) & 1 & 10 & & \\
\hline Dayton (U.S.A) & 1 & 10 & & \\
\hline \multirow[t]{3}{*}{$\begin{array}{r}\text { Watsonville } \\
\text { (U.S.A) }\end{array}$} & 2 & $5-5$ & & \\
\hline & & \multicolumn{3}{|c|}{ Jheh-2 intron 1} \\
\hline & $\mathrm{N}$ haplotype & $\mathrm{N}$ & Alignment & Mean diversity \\
\hline Paris (France) & 2 & $4-2$ & \multirow{6}{*}{$250 \mathrm{pb}$} & \multirow{6}{*}{0.0390} \\
\hline $\begin{array}{r}\text { Montpellier } \\
\text { (France) }\end{array}$ & 2 & $5-2$ & & \\
\hline Sapporo Japan) & 2 & $4-3$ & & \\
\hline Tokyo (Japan) & 4 & $2-2-1-1$ & & \\
\hline Dayton (U.S.A) & 3 & $4-2-1$ & & \\
\hline \multirow[t]{3}{*}{$\begin{array}{r}\text { Watsonville } \\
\text { (U.S.A) }\end{array}$} & 2 & $5-4$ & & \\
\hline & & \multicolumn{3}{|c|}{ Jheh-2 intron 2} \\
\hline & $\mathrm{N}$ haplotype & $\mathrm{N}$ & Alignment & Mean diversity \\
\hline Paris (France) & 1 & 8 & \multirow{4}{*}{$165 p b$} & \multirow{4}{*}{0.0214} \\
\hline $\begin{array}{r}\text { Montpellier } \\
\text { (France) }\end{array}$ & 3 & $4-3-2$ & & \\
\hline Sapporo Japan) & 1 & 10 & & \\
\hline Tokyo (Japan) & 1 & 8 & & \\
\hline
\end{tabular}




\begin{tabular}{|c|c|c|c|c|}
\hline Dayton (U.S.A) & 1 & 9 & & \\
\hline $\begin{array}{r}\text { Watsonville } \\
\text { (U.S.A) }\end{array}$ & 1 & 10 & & \\
\hline & & & Jheh-2 intro & \\
\hline & $\mathrm{N}$ haplotype & $\mathrm{N}$ & Alignment & Mean diversity \\
\hline Paris (France) & 1 & 8 & \multirow{6}{*}{$211 \mathrm{pb}$} & \multirow{6}{*}{0.0333} \\
\hline $\begin{array}{r}\text { Montpellier } \\
\text { (France) }\end{array}$ & 1 & 8 & & \\
\hline Sapporo Japan) & 1 & 10 & & \\
\hline Tokyo (Japan) & 2 & $5-4$ & & \\
\hline Dayton (U.S.A) & 2 & $4-2$ & & \\
\hline \multirow[t]{3}{*}{$\begin{array}{r}\text { Watsonville } \\
\text { (U.S.A) }\end{array}$} & 1 & 10 & & \\
\hline & & \multicolumn{3}{|c|}{ Jheh-3 intron 2} \\
\hline & $\mathrm{N}$ haplotype & $\mathrm{N}$ & Alignment & Mean diversity \\
\hline Paris (France) & 1 & 10 & \multirow{6}{*}{$118 p b$} & \multirow{6}{*}{0.0209} \\
\hline $\begin{array}{r}\text { Montpellier } \\
\text { (France) }\end{array}$ & 2 & $7-3$ & & \\
\hline Sapporo Japan) & 1 & 9 & & \\
\hline Tokyo (Japan) & 3 & $7-2-1$ & & \\
\hline Dayton (U.S.A) & 1 & 9 & & \\
\hline $\begin{array}{r}\text { Watsonville } \\
\text { (U.S.A) }\end{array}$ & 1 & 10 & & \\
\hline
\end{tabular}

44 Table S3. Pairwise genetic distance between genotypes. Bold values represent genetic diversity within 45 lines. 


\begin{tabular}{|c|c|c|c|c|c|c|}
\hline Jheh-1.1 & Paris & Montpellier & Sapporo & Tokyo & Dayton & Watsonville \\
\hline Paris & 0.0000 & & & & & \\
\hline Montpellier & 0.0104 & 0.0000 & & & & \\
\hline Sapporo & 0.0104 & 0.0000 & 0.0000 & & & \\
\hline Tokyo & 0.0208 & 0.0104 & 0.0104 & 0.0000 & & \\
\hline Dayton & 0.0105 & 0.0000 & 0.0000 & 0.0105 & 0.0000 & \\
\hline Watsonville & 0.0104 & 0.0000 & 0.0000 & 0.0104 & 0.0000 & 0.0792 \\
\hline Jheh-1.2 & Paris & Montpellier & Sapporo & Tokyo & Dayton & Watsonville \\
\hline Paris & 0.0000 & & & & & \\
\hline Montpellier & 0.0084 & 0.0169 & & & & \\
\hline Sapporo & 0.0000 & 0.0084 & 0.0000 & & & \\
\hline Tokyo & 0.0000 & 0.0084 & 0.0000 & 0.0000 & & \\
\hline Dayton & 0.0000 & 0.0084 & 0.0000 & 0.0000 & 0.0000 & \\
\hline Watsonville & 0.0000 & 0.0084 & 0.0000 & 0.0000 & 0.0000 & 0.0000 \\
\hline Jheh-1.3 & Paris & Montpellier & Sapporo & Tokyo & Dayton & Watsonville \\
\hline Paris & 0.0000 & & & & & \\
\hline Montpellier & 0.0079 & 0.0000 & & & & \\
\hline Sapporo & 0.0157 & 0.0236 & 0.0396 & & & \\
\hline Tokyo & 0.0079 & 0.0000 & 0.0236 & 0.0000 & & \\
\hline Dayton & 0.0238 & 0.0159 & 0.0379 & 0.0159 & 0.0000 & \\
\hline Watsonville & 0.0236 & 0.0157 & 0.0226 & 0.0157 & 0.0152 & 0.0198 \\
\hline Jheh-2.1 & Paris & Montpellier & Sapporo & Tokyo & Dayton & Watsonville \\
\hline Paris & 0.0460 & & & & & \\
\hline Montpellier & 0.0502 & 0.0502 & & & & \\
\hline Sapporo & 0.0546 & 0.0462 & 0.0546 & & & \\
\hline Tokyo & 0.0502 & 0.0167 & 0.0378 & 0.0324 & & \\
\hline
\end{tabular}




\begin{tabular}{|c|c|c|c|c|c|c|}
\hline Dayton & 0.0254 & 0.0466 & 0.0511 & 0.0466 & 0.0449 & \\
\hline Watsonville & 0.0502 & 0.0084 & 0.0462 & 0.0084 & 0.0466 & 0.0466 \\
\hline Jheh-2.2 & Paris & Montpellier & Sapporo & Tokyo & Dayton & Watsonville \\
\hline Paris & 0.0000 & & & & & \\
\hline Montpellier & 0.0121 & 0.0081 & & & & \\
\hline Sapporo & 0.0303 & 0.0303 & 0.0000 & & & \\
\hline Tokyo & 0.0061 & 0.0061 & 0.0242 & 0.0000 & & \\
\hline Dayton & 0.0364 & 0.0364 & 0.0242 & 0.0303 & 0.0000 & \\
\hline Watsonville & 0.0000 & 0.0121 & 0.0303 & 0.0061 & 0.0364 & 0.0000 \\
\hline Jheh-2.3 & Paris & Montpellier & Sapporo & Tokyo & Dayton & Watsonville \\
\hline Paris & 0.0000 & & & & & \\
\hline Montpellier & 0.0240 & 0.0000 & & & & \\
\hline Sapporo & 0.0144 & 0.0096 & 0.0000 & & & \\
\hline Tokyo & 0.0144 & 0.0096 & 0.0000 & 0.0144 & & \\
\hline Dayton & 0.0144 & 0.0096 & 0.0000 & 0.0000 & 0.0096 & \\
\hline Watsonville & 0.0825 & 0.0874 & 0.0777 & 0.0777 & 0.0777 & 0.0000 \\
\hline Jheh-3.2 & Paris & Montpellier & Sapporo & Tokyo & Dayton & Watsonville \\
\hline Paris & 0.0000 & & & & & \\
\hline Montpellier & 0.0339 & 0.0339 & & & & \\
\hline Sapporo & 0.0254 & 0.0085 & 0.0000 & & & \\
\hline Tokyo & 0.0339 & 0.0169 & 0.0085 & 0.0113 & & \\
\hline Dayton & 0.0000 & 0.0339 & 0.0254 & 0.0339 & 0.0000 & \\
\hline Watsonville & 0.0339 & 0.0169 & 0.0085 & 0.0000 & 0.0339 & 0.0000 \\
\hline
\end{tabular}


bioRxiv preprint doi: https://doi.org/10.1101/2020.04.27.063297; this version posted April 28, 2020. The copyright holder for this preprint (which was not certified by peer review) is the author/funder. All rights reserved. No reuse allowed without permission.

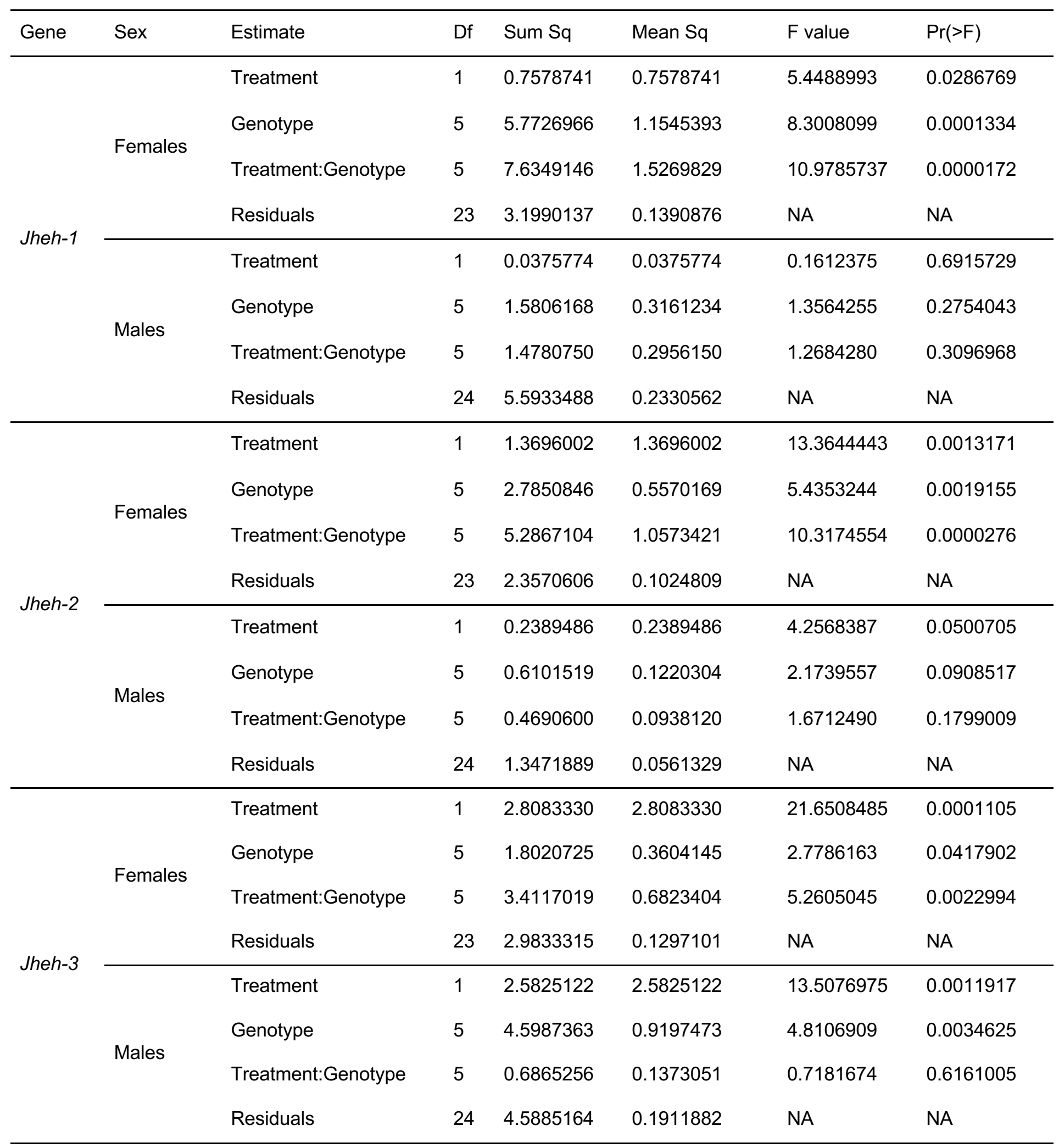

52

53

54

55

56

57

58

Table S5. TFBS and TE detected in all six genotypes and the reference genome of $D$.

suzukii. We screened TFBS in the intergenic regions before, between and after the Jheh genes.

57 The names of the transcription factors (TF) and transposable elements (TE) are given with their 58 positions in the sequence (beginning and end). 


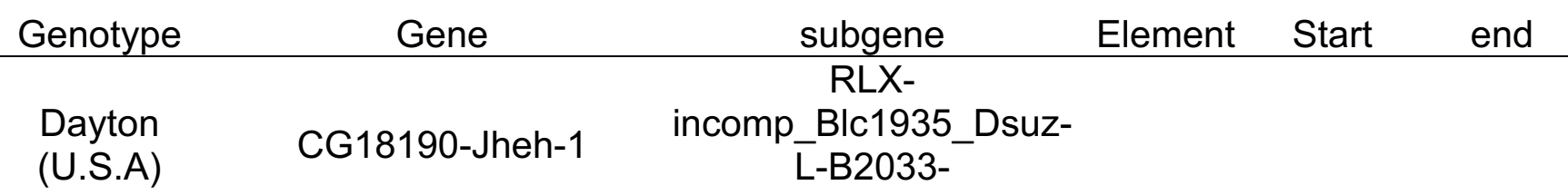

\begin{tabular}{|c|c|c|c|c|c|}
\hline & & Map1_reversed & TE & 3983310 & 3983388 \\
\hline $\begin{array}{l}\text { Montpellier } \\
\text { (France) }\end{array}$ & CG18190-Jheh-1 & $\begin{array}{c}\text { RXX_Blc1636_Dsuz-B- } \\
\text { R3220- } \\
\text { Map20_reversed }\end{array}$ & TE & 3983164 & 3983184 \\
\hline $\begin{array}{l}\text { Paris } \\
\text { (France) }\end{array}$ & CG18190-Jheh-1 & $\begin{array}{c}\text { RLX- } \\
\text { incomp_Blc1935_Dsuz- } \\
\text { L-B2033- } \\
\text { Map1_reversed }\end{array}$ & TE & 3983310 & 3983388 \\
\hline $\begin{array}{l}\text { Reference } \\
\text { genome }\end{array}$ & CG18190-Jheh-1 & $\begin{array}{c}\text { RLX- } \\
\text { incomp_Blc1935_Dsuz- } \\
\text { L-B2033- } \\
\text { Map1_reversed }\end{array}$ & TE & 3983310 & 3983388 \\
\hline $\begin{array}{c}\text { Sapporo } \\
\text { (Japan) }\end{array}$ & CG18190-Jheh-1 & $\begin{array}{c}\text { RLX- } \\
\text { incomp_Blc1935_Dsuz- } \\
\text { L-B2033- } \\
\text { Map1_reversed }\end{array}$ & TE & 3983310 & 3983388 \\
\hline $\begin{array}{l}\text { Tokyo } \\
\text { (Japan) }\end{array}$ & CG18190-Jheh-1 & $\begin{array}{c}\text { RXX- } \\
\text { LARD_Blc2842_Dsuz- } \\
\text { L-B3109- } \\
\text { Map1_reversed }\end{array}$ & TE & 3983339 & 3983380 \\
\hline $\begin{array}{l}\text { Watsonville } \\
\text { (U.S.A) }\end{array}$ & CG18190-Jheh-1 & $\begin{array}{c}\text { RLX- } \\
\text { incomp_Blc1935_Dsuz- } \\
\text { L-B2033- } \\
\text { Map1_reversed }\end{array}$ & TE & 3983312 & 3983390 \\
\hline $\begin{array}{l}\text { Dayton } \\
\text { (U.S.A) }\end{array}$ & Jheh-2-Jheh-3 & $\begin{array}{c}\text { RXX- } \\
\text { LARD_Blc2479_Dsuz- } \\
\text { L-B2652-Map1 }\end{array}$ & TE & 3988791 & 3988881 \\
\hline $\begin{array}{l}\text { Montpellier } \\
\text { (France) }\end{array}$ & Jheh-2-Jheh-3 & $\begin{array}{c}\text { RXX- } \\
\text { LARD_Blc2479_Dsuz- } \\
\text { L-B2652-Map1 }\end{array}$ & TE & 3988807 & 3988855 \\
\hline $\begin{array}{c}\text { Paris } \\
\text { (France) }\end{array}$ & Jheh-2-Jheh-3 & $\begin{array}{c}\text { RLX-incomp- } \\
\text { chim_Blc427_Dsuz-L- } \\
\text { B425-Map1 }\end{array}$ & TE & 3988909 & 3988949 \\
\hline $\begin{array}{l}\text { Reference } \\
\text { genome }\end{array}$ & Jheh-2-Jheh-3 & $\begin{array}{c}\text { RLX-incomp- } \\
\text { chim_Blc427_Dsuz-L- } \\
\text { B425-Map1 }\end{array}$ & TE & 3988910 & 3988950 \\
\hline $\begin{array}{l}\text { Sapporo } \\
\text { (Japan) }\end{array}$ & Jheh-2-Jheh-3 & $\begin{array}{c}\text { RXX- } \\
\text { LARD_Blc2479_Dsuz- } \\
\text { L-B2652-Map1 }\end{array}$ & TE & 3988804 & 3988850 \\
\hline $\begin{array}{l}\text { Tokyo } \\
\text { (Japan) }\end{array}$ & Jheh-2-Jheh-3 & $\begin{array}{c}\text { RXX- } \\
\text { LARD_Blc2479_Dsuz- } \\
\text { L-B2652-Map1 }\end{array}$ & TE & 3988805 & 3988853 \\
\hline $\begin{array}{l}\text { Dayton } \\
\text { (U.S.A) }\end{array}$ & Jheh-3-CG43069 & $\begin{array}{c}\text { RXX- } \\
\text { LARD_Blc5020_Dsuz- } \\
\text { L-B5102-Map1 }\end{array}$ & TE & 3991489 & 3991526 \\
\hline $\begin{array}{l}\text { Montpellier } \\
\text { (France) }\end{array}$ & Jheh-3-CG43069 & $\begin{array}{c}\text { RXX- } \\
\text { LARD_Blc4946_Dsuz- } \\
\text { L-B5036-Map1 }\end{array}$ & TE & 3991470 & 3991507 \\
\hline $\begin{array}{l}\text { Reference } \\
\text { genome }\end{array}$ & Jheh-3-CG43069 & $\begin{array}{c}\text { RXX-LARD- } \\
\text { chim_Blc2440_Dsuz-L- }\end{array}$ & TE & 3991670 & 3991701 \\
\hline
\end{tabular}




\begin{tabular}{|c|c|c|c|c|}
\hline & & B2608-Map1 & & \\
\hline $\begin{array}{l}\text { Sapporo } \\
\text { (Japan) }\end{array}$ & Jheh-3-CG43069 & $\begin{array}{c}\text { RYX- } \\
\text { incomp_Blc4021_Dsuz- } \\
\text { L-B4274-Map1 }\end{array}$ & TE & 39914493991507 \\
\hline $\begin{array}{l}\text { Tokyo } \\
\text { (Japan) }\end{array}$ & Jheh-3-CG43069 & $\begin{array}{c}\text { DHX- } \\
\text { incomp_Blc652_Dsuz- } \\
\text { B-R2897-Map20 }\end{array}$ & TE & 39916663991691 \\
\hline $\begin{array}{c}\text { Watsonville } \\
\text { (U.S.A) }\end{array}$ & Jheh-3-CG43069 & $\begin{array}{l}\text { RXX_Blc2359_Dsuz-B- } \\
\text { R8146-Map6_reversed }\end{array}$ & TE & 39915753991608 \\
\hline $\begin{array}{c}\text { Paris } \\
\text { (France) }\end{array}$ & Jheh-3-CG43069 & $\begin{array}{c}\text { RXX- } \\
\text { LARD_Blc434_Dsuz-L- } \\
\text { B429-Map1 }\end{array}$ & TE & 39915593991592 \\
\hline $\begin{array}{l}\text { Dayton } \\
\text { (U.S.A) }\end{array}$ & CG18190-Jheh-1 & cad & TF & 39832233983233 \\
\hline $\begin{array}{l}\text { Dayton } \\
\text { (U.S.A) }\end{array}$ & CG18190-Jheh-1 & cad & TF & 39828743982884 \\
\hline $\begin{array}{l}\text { Dayton } \\
\text { (U.S.A) }\end{array}$ & CG18190-Jheh-1 & Deaf1 & TF & 39832983983303 \\
\hline $\begin{array}{l}\text { Montpellier } \\
\text { (France) }\end{array}$ & CG18190-Jheh-1 & cad & TF & 39833353983345 \\
\hline $\begin{array}{l}\text { Montpellier } \\
\text { (France) }\end{array}$ & CG18190-Jheh-1 & cad & TF & 39828743982884 \\
\hline $\begin{array}{l}\text { Montpellier } \\
\text { (France) }\end{array}$ & CG18190-Jheh-1 & Ubx & TF & 39832233983230 \\
\hline $\begin{array}{l}\text { Montpellier } \\
\text { (France) }\end{array}$ & CG18190-Jheh-1 & Cf2 & TF & 39833193983328 \\
\hline $\begin{array}{c}\text { Paris } \\
\text { (France) }\end{array}$ & CG18190-Jheh-1 & Deaf1 & TF & 39832983983303 \\
\hline $\begin{array}{l}\text { Reference } \\
\text { genome }\end{array}$ & CG18190-Jheh-1 & cad & TF & 39832233983233 \\
\hline $\begin{array}{l}\text { Reference } \\
\text { genome }\end{array}$ & CG18190-Jheh-1 & cad & TF & 39828743982884 \\
\hline $\begin{array}{l}\text { Reference } \\
\text { genome }\end{array}$ & CG18190-Jheh-1 & Deaf1 & TF & 39832983983303 \\
\hline $\begin{array}{l}\text { Sapporo } \\
\text { (Japan) }\end{array}$ & CG18190-Jheh-1 & cad & TF & 39832233983233 \\
\hline $\begin{array}{l}\text { Sapporo } \\
\text { (Japan) }\end{array}$ & CG18190-Jheh-1 & cad & TF & 39828743982884 \\
\hline $\begin{array}{l}\text { Sapporo } \\
\text { (Japan) }\end{array}$ & CG18190-Jheh-1 & Deaf1 & TF & 39832983983303 \\
\hline $\begin{array}{l}\text { Tokyo } \\
\text { (Japan) }\end{array}$ & CG18190-Jheh-1 & cad & TF & 39832233983233 \\
\hline $\begin{array}{c}\text { Tokyo } \\
\text { (Japan) }\end{array}$ & CG18190-Jheh-1 & cad & TF & 39828743982884 \\
\hline $\begin{array}{l}\text { Tokyo } \\
\text { (Japan) }\end{array}$ & CG18190-Jheh-1 & Deaf1 & TF & 39832983983303 \\
\hline $\begin{array}{l}\text { Watsonville } \\
\text { (U.S.A) }\end{array}$ & CG18190-Jheh-1 & cad & TF & 39832253983235 \\
\hline $\begin{array}{l}\text { Watsonville } \\
\text { (U.S.A) }\end{array}$ & CG18190-Jheh-1 & cad & TF & 39828743982884 \\
\hline $\begin{array}{l}\text { Watsonville } \\
\text { (U.S.A) }\end{array}$ & CG18190-Jheh-1 & Deaf1 & TF & 39833003983305 \\
\hline Dayton & Jheh-1-Jheh-2 & cad & TF & 39856923985702 \\
\hline
\end{tabular}


(U.S.A)

\begin{tabular}{|c|c|c|c|c|}
\hline $\begin{array}{l}\text { Dayton } \\
\text { (U.S.A) }\end{array}$ & Jheh-1-Jheh-2 & Deaf1 & TF & 39853423985347 \\
\hline $\begin{array}{l}\text { Dayton } \\
\text { (U.S.A) }\end{array}$ & Jheh-1-Jheh-2 & br(var.4) & TF & 39853713985381 \\
\hline $\begin{array}{c}\text { Montpellier } \\
\text { (France) }\end{array}$ & Jheh-1-Jheh-2 & cad & TF & 39856923985702 \\
\hline $\begin{array}{c}\text { Montpellier } \\
\text { (France) }\end{array}$ & Jheh-1-Jheh-2 & Deaf1 & TF & 39853413985346 \\
\hline $\begin{array}{c}\text { Montpellier } \\
\text { (France) }\end{array}$ & Jheh-1-Jheh-2 & Deaf1 & TF & 39854073985412 \\
\hline $\begin{array}{c}\text { Paris } \\
\text { (France) }\end{array}$ & Jheh-1-Jheh-2 & Deaf1 & TF & 39853423985347 \\
\hline $\begin{array}{c}\text { Paris } \\
\text { (France) }\end{array}$ & Jheh-1-Jheh-2 & Deaf1 & TF & 39854083985413 \\
\hline $\begin{array}{c}\text { Reference } \\
\text { genome }\end{array}$ & Jheh-1-Jheh-2 & cad & TF & 39856943985704 \\
\hline $\begin{array}{c}\text { Reference } \\
\text { genome }\end{array}$ & Jheh-1-Jheh-2 & Deaf1 & TF & $3985343 \quad 3985348$ \\
\hline $\begin{array}{c}\text { Reference } \\
\text { genome }\end{array}$ & Jheh-1-Jheh-2 & Deaf1 & TF & 39854093985414 \\
\hline $\begin{array}{l}\text { Sapporo } \\
\text { (Japan) }\end{array}$ & Jheh-1-Jheh-2 & cad & TF & 39856803985690 \\
\hline $\begin{array}{l}\text { Sapporo } \\
\text { (Japan) }\end{array}$ & Jheh-1-Jheh-2 & Deaf1 & TF & 39853413985346 \\
\hline $\begin{array}{c}\text { Sapporo } \\
\text { (Japan) }\end{array}$ & Jheh-1-Jheh-2 & br(var.4) & TF & 39853703985380 \\
\hline $\begin{array}{l}\text { Tokyo } \\
\text { (Japan) }\end{array}$ & Jheh-1-Jheh-2 & cad & TF & 39856913985701 \\
\hline $\begin{array}{c}\text { Tokyo } \\
\text { (Japan) }\end{array}$ & Jheh-1-Jheh-2 & Deaf1 & TF & 39853413985346 \\
\hline $\begin{array}{l}\text { Tokyo } \\
\text { (Japan) }\end{array}$ & Jheh-1-Jheh-2 & $\operatorname{br}(\operatorname{var} .4)$ & TF & 39853703985380 \\
\hline $\begin{array}{c}\text { Watsonville } \\
\text { (U.S.A) }\end{array}$ & Jheh-1-Jheh-2 & cad & TF & 39857003985710 \\
\hline $\begin{array}{c}\text { Watsonville } \\
\text { (U.S.A) }\end{array}$ & Jheh-1-Jheh-2 & Deaf1 & TF & 39853503985355 \\
\hline $\begin{array}{c}\text { Watsonville } \\
\text { (U.S.A) }\end{array}$ & Jheh-1-Jheh-2 & br(var.4) & TF & 39853793985389 \\
\hline $\begin{array}{l}\text { Dayton } \\
\text { (U.S.A) }\end{array}$ & Jheh-2-Jheh-3 & cnc::maf-S & TF & 39880413988055 \\
\hline $\begin{array}{l}\text { Dayton } \\
\text { (U.S.A) }\end{array}$ & Jheh-2-Jheh-3 & Ubx & TF & 39886783988685 \\
\hline $\begin{array}{c}\text { Montpellier } \\
\text { (France) }\end{array}$ & Jheh-2-Jheh-3 & cad & TF & 39894503989460 \\
\hline $\begin{array}{c}\text { Montpellier } \\
\text { (France) }\end{array}$ & Jheh-2-Jheh-3 & cnc::maf-S & TF & 39880433988057 \\
\hline $\begin{array}{c}\text { Montpellier } \\
\text { (France) }\end{array}$ & Jheh-2-Jheh-3 & $\mathrm{hb}$ & TF & 39892173989226 \\
\hline $\begin{array}{c}\text { Montpellier } \\
\text { (France) }\end{array}$ & Jheh-2-Jheh-3 & $\mathrm{hb}$ & TF & 39894523989461 \\
\hline $\begin{array}{c}\text { Montpellier } \\
\text { (France) }\end{array}$ & Jheh-2-Jheh-3 & Ubx & TF & 39886843988691 \\
\hline
\end{tabular}




\begin{tabular}{|c|c|c|c|c|}
\hline $\begin{array}{l}\text { Montpellier } \\
\text { (France) }\end{array}$ & Jheh-2-Jheh-3 & Ubx & TF & 39887773988784 \\
\hline $\begin{array}{l}\text { Paris } \\
\text { (France) }\end{array}$ & Jheh-2-Jheh-3 & cad & TF & 39887013988711 \\
\hline $\begin{array}{c}\text { Paris } \\
\text { (France) }\end{array}$ & Jheh-2-Jheh-3 & cnc::maf-S & TF & 39880433988057 \\
\hline $\begin{array}{c}\text { Paris } \\
\text { (France) }\end{array}$ & Jheh-2-Jheh-3 & $\mathrm{hb}$ & TF & 39886793988688 \\
\hline $\begin{array}{c}\text { Paris } \\
\text { (France) }\end{array}$ & Jheh-2-Jheh-3 & Ubx & TF & 39887643988771 \\
\hline $\begin{array}{l}\text { Reference } \\
\text { genome }\end{array}$ & Jheh-2-Jheh-3 & $\mathrm{dl}$ & TF & 39879043987915 \\
\hline $\begin{array}{c}\text { Reference } \\
\text { genome }\end{array}$ & Jheh-2-Jheh-3 & cad & TF & 39887023988712 \\
\hline $\begin{array}{l}\text { Reference } \\
\text { genome }\end{array}$ & Jheh-2-Jheh-3 & cnc::maf-S & TF & 39880443988058 \\
\hline $\begin{array}{c}\text { Reference } \\
\text { genome }\end{array}$ & Jheh-2-Jheh-3 & $\mathrm{hb}$ & TF & 39886803988689 \\
\hline $\begin{array}{l}\text { Reference } \\
\text { genome }\end{array}$ & Jheh-2-Jheh-3 & Ubx & TF & 39887653988772 \\
\hline $\begin{array}{l}\text { Sapporo } \\
\text { (Japan) }\end{array}$ & Jheh-2-Jheh-3 & cad & TF & 39885943988604 \\
\hline $\begin{array}{l}\text { Sapporo } \\
\text { (Japan) }\end{array}$ & Jheh-2-Jheh-3 & cnc::maf-S & TF & 39880433988057 \\
\hline $\begin{array}{l}\text { Sapporo } \\
\text { (Japan) }\end{array}$ & Jheh-2-Jheh-3 & $\mathrm{hb}$ & TF & 39891893989198 \\
\hline $\begin{array}{l}\text { Sapporo } \\
\text { (Japan) }\end{array}$ & Jheh-2-Jheh-3 & Ubx & TF & 39886833988690 \\
\hline $\begin{array}{l}\text { Sapporo } \\
\text { (Japan) }\end{array}$ & Jheh-2-Jheh-3 & Ubx & TF & 39887743988781 \\
\hline $\begin{array}{l}\text { Tokyo } \\
\text { (Japan) }\end{array}$ & Jheh-2-Jheh-3 & cnc::maf-S & TF & 39880423988056 \\
\hline $\begin{array}{l}\text { Tokyo } \\
\text { (Japan) }\end{array}$ & Jheh-2-Jheh-3 & $\mathrm{hb}$ & TF & 39892153989224 \\
\hline $\begin{array}{c}\text { Watsonville } \\
\text { (U.S.A) }\end{array}$ & Jheh-2-Jheh-3 & cad & TF & 39888093988819 \\
\hline $\begin{array}{l}\text { Watsonville } \\
\text { (U.S.A) }\end{array}$ & Jheh-2-Jheh-3 & cnc::maf-S & TF & 39880423988056 \\
\hline $\begin{array}{l}\text { Watsonville } \\
\text { (U.S.A) }\end{array}$ & Jheh-2-Jheh-3 & $\mathrm{hb}$ & TF & 39887903988799 \\
\hline $\begin{array}{l}\text { Dayton } \\
\text { (U.S.A) }\end{array}$ & Jheh-3-CG43069 & ARNT::HIF1A & TF & 39916983991705 \\
\hline $\begin{array}{l}\text { Dayton } \\
\text { (U.S.A) }\end{array}$ & Jheh-3-CG43069 & cad & TF & 39913373991347 \\
\hline $\begin{array}{l}\text { Dayton } \\
\text { (U.S.A) }\end{array}$ & Jheh-3-CG43069 & cad & TF & 39918743991884 \\
\hline $\begin{array}{l}\text { Dayton } \\
\text { (U.S.A) }\end{array}$ & Jheh-3-CG43069 & cad & TF & 39918453991855 \\
\hline $\begin{array}{l}\text { Dayton } \\
\text { (U.S.A) }\end{array}$ & Jheh-3-CG43069 & Deaf1 & TF & 39911823991187 \\
\hline $\begin{array}{l}\text { Dayton } \\
\text { (U.S.A) }\end{array}$ & Jheh-3-CG43069 & Deaf1 & TF & 39910063991011 \\
\hline Dayton & Jheh-3-CG43069 & Ubx & TF & 39913513991358 \\
\hline
\end{tabular}


(U.S.A)

\begin{tabular}{|c|c|c|c|c|}
\hline $\begin{array}{c}\text { Montpellier } \\
\text { (France) }\end{array}$ & Jheh-3-CG43069 & ARNT::HIF1A & TF & 39918773991884 \\
\hline $\begin{array}{c}\text { Montpellier } \\
\text { (France) }\end{array}$ & Jheh-3-CG43069 & cad & TF & 39920543992064 \\
\hline $\begin{array}{c}\text { Montpellier } \\
\text { (France) }\end{array}$ & Jheh-3-CG43069 & cad & TF & 39920243992034 \\
\hline $\begin{array}{l}\text { Montpellier } \\
\text { (France) }\end{array}$ & Jheh-3-CG43069 & Deaf1 & TF & 39911823991187 \\
\hline $\begin{array}{c}\text { Montpellier } \\
\text { (France) }\end{array}$ & Jheh-3-CG43069 & Deaf1 & TF & 39917443991749 \\
\hline $\begin{array}{c}\text { Montpellier } \\
\text { (France) }\end{array}$ & Jheh-3-CG43069 & Deaf1 & TF & 39910063991011 \\
\hline $\begin{array}{c}\text { Montpellier } \\
\text { (France) }\end{array}$ & Jheh-3-CG43069 & Ubx & TF & 39915893991596 \\
\hline $\begin{array}{l}\text { Reference } \\
\text { genome }\end{array}$ & Jheh-3-CG43069 & cad & TF & 39919333991943 \\
\hline $\begin{array}{c}\text { Reference } \\
\text { genome }\end{array}$ & Jheh-3-CG43069 & cad & TF & 39916743991684 \\
\hline $\begin{array}{c}\text { Reference } \\
\text { genome }\end{array}$ & Jheh-3-CG43069 & cad & TF & 39916963991706 \\
\hline $\begin{array}{c}\text { Reference } \\
\text { genome }\end{array}$ & Jheh-3-CG43069 & cad & TF & 39919033991913 \\
\hline $\begin{array}{c}\text { Reference } \\
\text { genome }\end{array}$ & Jheh-3-CG43069 & Deaf1 & TF & 39911823991187 \\
\hline $\begin{array}{c}\text { Reference } \\
\text { genome }\end{array}$ & Jheh-3-CG43069 & $\mathrm{hb}$ & TF & 39916953991704 \\
\hline $\begin{array}{c}\text { Reference } \\
\text { genome }\end{array}$ & Jheh-3-CG43069 & Ubx & TF & 39916673991674 \\
\hline $\begin{array}{l}\text { Sapporo } \\
\text { (Japan) }\end{array}$ & Jheh-3-CG43069 & cad & TF & $3992103 \quad 3992113$ \\
\hline $\begin{array}{l}\text { Sapporo } \\
\text { (Japan) }\end{array}$ & Jheh-3-CG43069 & cad & TF & 39918443991854 \\
\hline $\begin{array}{l}\text { Sapporo } \\
\text { (Japan) }\end{array}$ & Jheh-3-CG43069 & cad & TF & 39918663991876 \\
\hline $\begin{array}{l}\text { Sapporo } \\
\text { (Japan) }\end{array}$ & Jheh-3-CG43069 & cad & TF & 39920733992083 \\
\hline $\begin{array}{c}\text { Sapporo } \\
\text { (Japan) }\end{array}$ & Jheh-3-CG43069 & Deaf1 & TF & 39911823991187 \\
\hline $\begin{array}{l}\text { Sapporo } \\
\text { (Japan) }\end{array}$ & Jheh-3-CG43069 & $\mathrm{hb}$ & TF & 39915723991581 \\
\hline $\begin{array}{l}\text { Sapporo } \\
\text { (Japan) }\end{array}$ & Jheh-3-CG43069 & $\mathrm{hb}$ & TF & 39918653991874 \\
\hline $\begin{array}{c}\text { Sapporo } \\
\text { (Japan) }\end{array}$ & Jheh-3-CG43069 & Ubx & TF & 39915973991604 \\
\hline $\begin{array}{l}\text { Sapporo } \\
\text { (Japan) }\end{array}$ & Jheh-3-CG43069 & Ubx & TF & 39918373991844 \\
\hline $\begin{array}{l}\text { Tokyo } \\
\text { (Japan) }\end{array}$ & Jheh-3-CG43069 & cad & TF & 39919243991934 \\
\hline $\begin{array}{l}\text { Tokyo } \\
\text { (Japan) }\end{array}$ & Jheh-3-CG43069 & cad & TF & 39916653991675 \\
\hline $\begin{array}{l}\text { Tokyo } \\
\text { (Japan) }\end{array}$ & Jheh-3-CG43069 & cad & TF & 39918943991904 \\
\hline
\end{tabular}




\begin{tabular}{|c|c|c|c|c|c|}
\hline $\begin{array}{l}\text { Tokyo } \\
\text { (Japan) }\end{array}$ & Jheh-3-CG43069 & Deaf1 & TF & 3991176 & 3991181 \\
\hline $\begin{array}{c}\text { Tokyo } \\
\text { (Japan) }\end{array}$ & Jheh-3-CG43069 & Ubx & TF & 3991688 & 3991695 \\
\hline $\begin{array}{l}\text { Tokyo } \\
\text { (Japan) }\end{array}$ & Jheh-3-CG43069 & Ubx & TF & 3991281 & 3991288 \\
\hline $\begin{array}{c}\text { Watsonville } \\
\text { (U.S.A) }\end{array}$ & Jheh-3-CG43069 & ARNT::HIF1A & TF & 3991698 & 3991705 \\
\hline $\begin{array}{c}\text { Watsonville } \\
\text { (U.S.A) }\end{array}$ & Jheh-3-CG43069 & cad & TF & 3991337 & 3991347 \\
\hline $\begin{array}{c}\text { Watsonville } \\
\text { (U.S.A) }\end{array}$ & Jheh-3-CG43069 & cad & TF & 3991877 & 3991887 \\
\hline $\begin{array}{c}\text { Watsonville } \\
\text { (U.S.A) }\end{array}$ & Jheh-3-CG43069 & Deaf1 & TF & 3991182 & 3991187 \\
\hline $\begin{array}{c}\text { Watsonville } \\
\text { (U.S.A) }\end{array}$ & Jheh-3-CG43069 & Ubx & $\mathrm{TF}$ & 3991351 & 3991358 \\
\hline $\begin{array}{c}\text { Paris } \\
\text { (France) }\end{array}$ & Jheh-3-CG43069 & ARNT::HIF1A & $\mathrm{TF}$ & 3991784 & 3991791 \\
\hline $\begin{array}{c}\text { Paris } \\
\text { (France) }\end{array}$ & Jheh-3-CG43069 & cad & TF & 3991961 & 3991971 \\
\hline $\begin{array}{c}\text { Paris } \\
\text { (France) }\end{array}$ & Jheh-3-CG43069 & cad & $\mathrm{TF}$ & 3991368 & 3991378 \\
\hline $\begin{array}{c}\text { Paris } \\
\text { (France) }\end{array}$ & Jheh-3-CG43069 & cad & TF & 3991686 & 3991696 \\
\hline $\begin{array}{c}\text { Paris } \\
\text { (France) }\end{array}$ & Jheh-3-CG43069 & cad & $\mathrm{TF}$ & 3991931 & 3991941 \\
\hline $\begin{array}{c}\text { Paris } \\
\text { (France) }\end{array}$ & Jheh-3-CG43069 & Deaf1 & $\mathrm{TF}$ & 3991177 & 3991182 \\
\hline $\begin{array}{c}\text { Paris } \\
\text { (France) }\end{array}$ & Jheh-3-CG43069 & $\mathrm{hb}$ & $\mathrm{TF}$ & 3991367 & 3991376 \\
\hline $\begin{array}{c}\text { Paris } \\
\text { (France) }\end{array}$ & Jheh-3-CG43069 & Ubx & $\mathrm{TF}$ & 3991408 & 3991415 \\
\hline $\begin{array}{c}\text { Paris } \\
\text { (France) }\end{array}$ & Jheh-3-CG43069 & Ubx & TF & 3991412 & 3991419 \\
\hline $\begin{array}{c}\text { Paris } \\
\text { (France) }\end{array}$ & Jheh-3-CG43069 & Ubx & $\mathrm{TF}$ & 3991346 & 3991353 \\
\hline $\begin{array}{c}\text { Paris } \\
\text { (France) }\end{array}$ & Jheh-3-CG43069 & Ubx & TF & 3991410 & 3991417 \\
\hline $\begin{array}{c}\text { Paris } \\
\text { (France) }\end{array}$ & Jheh-3-CG43069 & Ubx & TF & 3991414 & 3991421 \\
\hline
\end{tabular}

